\title{
White pottery production in the Middle Meuse valley: sustainability of clay resources during the early Middle Ages
}

\author{
Line Van Wersch ${ }^{1,2} \cdot$ Sylvie de Longueville ${ }^{3}$. Laure Dussubieux ${ }^{4}$. Nathalie Fagel ${ }^{5}$. Frédéric Hatert ${ }^{5}$. \\ Patrick Degryse ${ }^{2,6}$
}

Received: 24 September 2019 / Accepted: 29 March 2020 / Published online: 29 June 2020

(C) The Author(s) 2020

\begin{abstract}
This study of white pottery from the Merovingian and Carolingian periods traces the use of white clay resources in the Middle Meuse valley at the beginning of the Middle Ages. The petrographic study of 56 sherds, the chemical analysis of 40 samples, and XRD study of 12 of them coming from 4 sites reach the changes of the process between the two time periods, characterize the production of three Carolingian workshops, and consider the material supply in the mechanism of potters' settlement. It appears that, between the Antiquity and the Modern period, the white kaolinitic material has always been exploited. The main technical changes between the Merovingian and the Carolingian periods are related to the specific selection of these clays that allow to produce white pottery and cooking wares with few inclusions. The Carolingian workshops used the material available in their environment that can be differentiated by chemistry and mineralogy. Finally, it appears that the selection of this particular type of clay also oriented the choice of the place where the potters settled or at least the longevity of some of the workshops.
\end{abstract}

Keywords Ceramic $\cdot$ Early Middle Ages $\cdot$ Sustainability of resources $\cdot$ Kaolinitic clay $\cdot$ Technical changes

\section{Introduction}

At the collapse of the Western Roman Empire, from end of the fifth century, the political and economic center was redirected north, and the Meuse and Rhine rivers became the focal axis of Europe, especially with the rise of the Carolingians, around the middle of the eighth century. From that period, as reflected by the multiplication of written documents, the power of the nobility increased so much that the elites reorganized the rural world, namely through the development of the bipartite manorial complexes (Verhulst 2002). Socio-economic changes took place also due to the growing supremacy of Christianity which intensified

Electronic supplementary material The online version of this article (https://doi.org/10.1007/s12520-020-01103-4) contains supplementary material, which is available to authorized users.

Line Van Wersch

line.vanwersch@uliege.be

1 UR Art, Archéologie, Patrimoine, Liege University, Liège, Belgium

2 Faculty of Archaeology, University of Leiden, Einsteinweg 2, 2333 CC Leiden, The Netherlands the abbey and churches' foundations (Lebecq 2000). In addition, the Emporia, ports of trade on the coasts of the North Sea, was closely related to the rise of the Carolingian fiscal system (Tys and Loveluck 2006). These sites had a clear commercial orientation as shown by the numerous traces of craft activities (Henning 2007). At the same time, the production traces disappeared from the Merovingian agglomerations (Theuws 2007). Henning's work (2007), through a systematic analysis of the archeological evidence for crafts and manufacturing in the Frankish Empire, gathers evidence of artisanal production over five centuries and concludes that the Carolingian period reached a high point in the creation of non-urban crafts. 
Regarding potters' activities in the Mosan valley, it appears that during the Merovingian period, especially in the sixth and seventh centuries, these craftsmen were settled in agglomerations such as in Maastricht, Huy, and Namur (Van Wersch 2016). After that period, they left no traces of their activities in these localities which leads to wonder: "Where is the $8^{\text {th }}$ century?" (Theuws 2007). Then, from at least the middle of the tenth century until the first known Andenne's productions during the middle of the eleventh century, ceramics was mostly produced in the rural environment where these activities were part of the economy of settlements, at the origin of present villages (Vanmechelen 2007).

Looking at the pottery, it is noticeable that this change in the potters' settlement strategy goes hand in hand with changes in the produced wares. Merovingian ceramic, largely wheel thrown, corresponds mainly to cooking pots and vessels used for the consumption of beverages and food. The first are coarse ovoid pots and the second are fine biconical dark pots or red carinated bowls (Siegmund 1998, Legoux et al. 2010, Van Wersch 2011). These forms display different morphological variations. With the Carolingian period, the red and dark wares were replaced by white, cream, or pinkish products. The morphological repertory shrank from multiple forms to mainly globular pots and to some carinated bowls (Gross 1991; Châtelet 2002; de Longueville 2008; Challe et al. 2014). Painted ceramic also reappears from that time and glazing that disappeared with Roman ceramics was reintroduced (Verhaeghe 1968, 1969; Hurst 1969; Châtelet 2002). If the Merovingian pottery seemed diffused from various workshops on a regional scale (Châtelet 2002; Van Wersch 2011), during the Carolingian period, in France, as in the Rhineland, a more centralized production was organized. Their products were spread over greater distances, such as the wares of Bardorf (Rhineland) distributed up to Scandinavia (Verhaeghe 2003).

Pottery was an everyday product and few reasons could explain the need for the elite to exert tight control over it (Costin 2000). Still, between the Merovingian and the Carolingian period, the rapid transition to white, cream, or pinkish wares in quite a large territory leads M. Châtelet (2002) to assert that the decision to centralize the workshops was taken by the political power. According to her, aristocrats were the only ones able to stop and replace the previous production system. In our point of view, next to the role of the elite, other factors could have been responsible for these transformations in the organization of the production. The raw material supply is certainly an aspect to consider. The cream wares required particular types of clays (Borremans and Warginaire 1966; de Longueville and Plumier 2007) and this certainly influenced the location of the potters' workshops.

In Belgium, on its middle course, the Meuse river is surrounded by the Hesbaye plains in the North and the Condroz hills in the South. Although the Hesbaye has rich agricultural land, the Condroz holds many geological resources, among which clays of various qualities. Looking at the location of the potters' workshops (Fig. 1), clay can come from two main sources. The alluvial clays are available in the Meuse valley as well as on the courses of smaller rivers. In these deposits, clays are mixed with silt, sand, and gravel (Goemaere 2017). Next to these, in horizontal deposits and karstic cavities, lies a white kaolinitic clay called "derle" (Goemaere 2017). The written sources proved that the quality of this plastic earth has been recognized since the late Middle Ages and, in the seventeenth century, it was exported as raw material on an international scale (Goemaere and Quinif 2010). Archeological pottery shows that this type of material was used by Roman potters (Rekk et al. 2014; Hanut and Vanmechelen 2017). It was then exploited systematically from the eleventh century for the "Andenne ceramic" that was exported on large scale (Borremans and Warginaire 1966). Between these periods, it is not clear if this white clay was used.

After antiquity, potters' workshops are attested in the region. Situated near the river, the Merovingian workshops of Huy and Maastricht exploited mainly local resources and alluvial clay of the Meuse valley. A mix of alluvial and kaolinitic clays is also assumed for some of the sherds of Huy (Van Wersch et al. 2015). Next to these, in Namur, pottery kilns were recently discovered (Vanmechelen 2007; Vanmechelen et al. 2007; Vanmechelen and de Longueville 2007a; Vanmechelen 2013; de Longueville and Vanmechelen 2017; Vanmechelen et al. 2018; Bosquet et al. 2018). In these production places, as in most of the consumption sites, Merovingian ceramic was gray to black, or red. However, in Ohey, a site identified as a Merovingian settlement from the seventh century, a special type of white pottery, was found. Predominant in the material, it has a white and fine paste and a white or dark surface. It probably comes from a workshop situated in the vicinity. These particular Merovingian white products might be related to the Carolingians white, cream, or pinkish pottery produced particularly in Haillot, Gérin, and Visé. The potters might have used the same material and/or related techniques.

\section{Aims}

This paper aims to evaluate the sustainability of white clay resources in the Mosan region over nearly five centuries, at the very beginning of the medieval period. Next to the morphological modifications of the wares, the clay preparation and the transformations of this process will be assessed. Then, the Carolingian productions from the Meuse valley will be characterized in order to allow further comparisons with other consumption sites. Finally, considering the possibilities for 
Fig. 1 Map locating the region studied and location of the sites studied in the Middle Meuse region (present-day Belgium) (maps from geoportail.wallonie and F. Theuws)

material supply, this paper will discuss the mechanisms of craft organization and its settlement process.

\section{Sites and material}

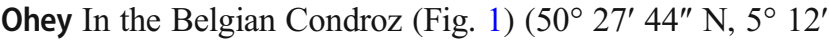
$\left.01^{\prime \prime} \mathrm{E}\right){ }^{1}$ situated in the valley of a small river, a dark organic layer containing ceramic sherds, flints fragments, burned cob, and charcoal was excavated on $10 \mathrm{~m}^{2}$. Even if no particular structure or building was discovered, this site corresponds to the waster area of a living place (Vrielynck and Dosogne 2001).

One thousand six hundred thirty-six sherds were discovered in this layer, among them 180 were rims. No shape was complete but the upper parts of the wares can be recognized to be ovoid pots, carinated and hemispheric bowls, or biconical pots, some of these decorated with rouletting. If some sherds were red or gray, $49 \%$ of them (83 rims) had a whitish and very fine clay matrix containing quartz and some iron oxides.

${ }^{1}$ The sites coordinates are calculated from: https://twcc.fr/.
The quantity of inclusions and their size vary according to the type of wares. The paste of the vessel with a smooth surface is finer than one of the cooking pots with a rough surface. For both types, their outer color can be white or dark because of a smoked layer (Figs. 2 and $3 \mathrm{a}$ and b). From a typological point of view, the forms were dated from the middle of the sixth to the seventh century (Van Wersch and Vrielynck 2008).

Haillot In Belgium, Haillot is situated at about $5 \mathrm{~km}$ away from the Merovingian site of Ohey (Fig. 1) $\left(50^{\circ} 26^{\prime} 21^{\prime \prime} \mathrm{N}\right.$, $\left.5^{\circ} 08^{\prime} 49^{\prime \prime} \mathrm{E}\right)$. Pottery kilns have been found in the area corresponding to the western part of a large settlement established during the tenth century (Vanmechelen 2007; Vanmechelen and de Longueville 2007, b; de Longueville 2015). It holds about ten housing units, each with the main building (over $100 \mathrm{~m}^{2}$ with both housing and stalling), many annex structures, and a few domestic ovens. The western area includes a house with several small wooden buildings around it. Seven pottery kilns, most of which overlap, are located in the immediate proximity of this construction. All of them are kilns with a central pillar and lateral heating channels. Their sizes are similar (total L, 2.53 to $3.46 \mathrm{~m} ; 1,1.02$ to $1.56 \mathrm{~m}$ ) and their 


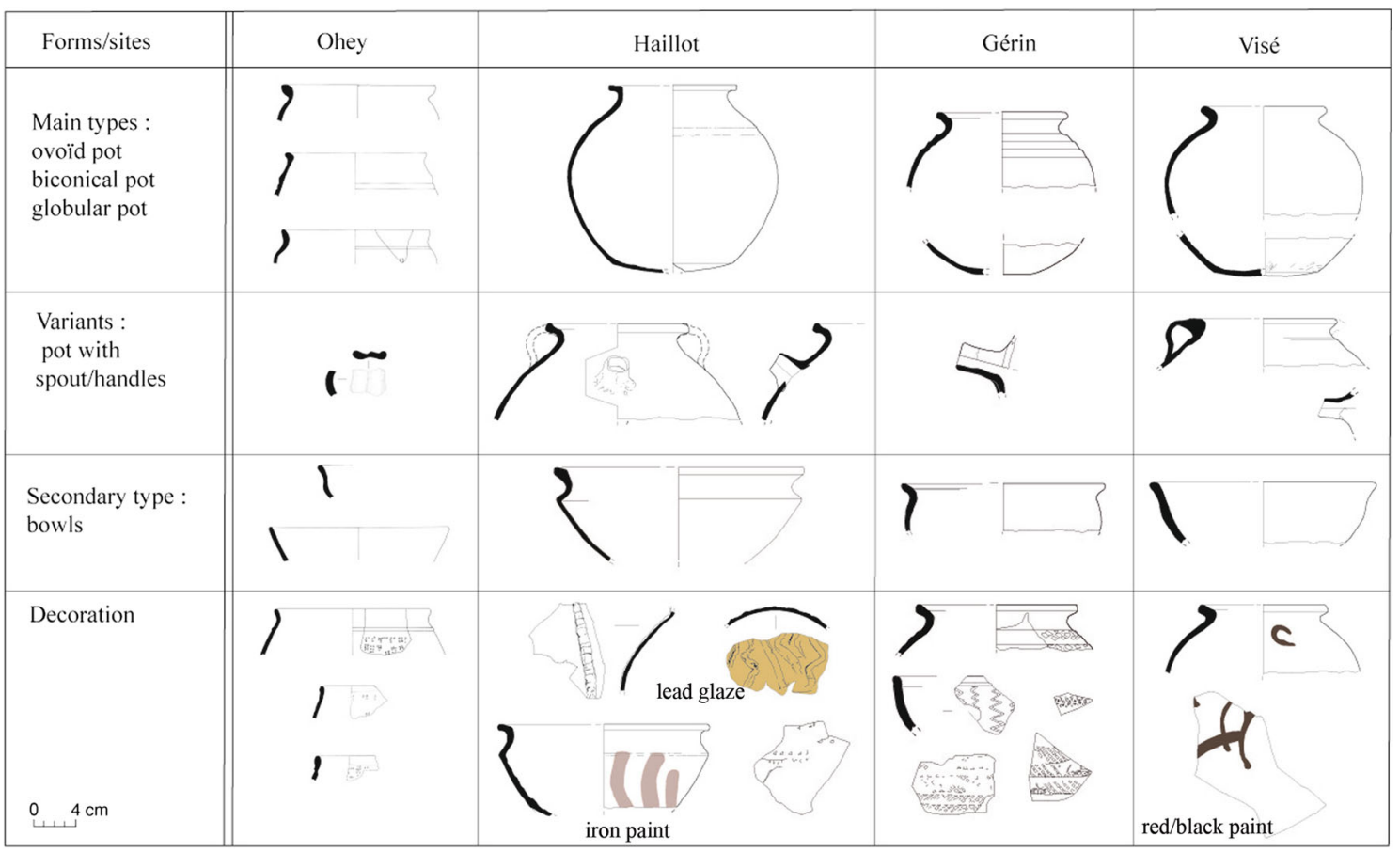

Fig. 2 Summary of the ceramic forms by site

walls were frequently recoated with a highly fired layer of clay. Many pits have been excavated, one of which still contained several pieces of raw clay. The discovery of an eighth kiln, $170 \mathrm{~m}$ to the east, within a parceled settlement, clearly shows that ceramic production was not the prerogative of one single workshop. The pottery kilns have been dated by typological studies and archeomagnetic analysis from the tenth to the eleventh centuries (Vanmechelen and de Longueville 2007b).

The accurate quantification of the material found is not completed yet but several thousands of sherds have been brought to light. The typological inventory, although partial, is largely dominated by globular pots, with flat or slightly lenticular bases, sometimes with flat handles and/or tubular spout. The open forms are essentially represented by the bowls with high and marked careen and with lips of various forms. Several decoration types exist, sometimes associated with the same vessel: lead glaze, iron paint, rouletting, applied strips, or bosses. After firing, the matrix is usually whitish and contains quartz and rare iron oxides. (Figs. 2 and $3 \mathrm{c}$ and d).

Visé In current Belgium, Visé is located at the fringe of the lower-Meuse valley and present-day Netherlands (Fig. 1) $\left(50^{\circ}\right.$ $43^{\prime} 41^{\prime \prime} \mathrm{N}, 5^{\circ} 41^{\prime} 39^{\prime \prime} \mathrm{E}$ ); this settlement seems to have grown from the second half of the ninth century. Written sources attested a seasonal trade fair that existed since the beginning of the tenth century (Zoller 1974). Archeologists discovered an overfired red layer forming a slightly oval shape (about $1 \mathrm{~m}$ of diameter) and identified it as a very eroded pottery kiln (de Longueville 2009).

One thousand three hundred sixty-nine cracked, deformed, or overfired sherds were deposited in this structure, among which 135 are coming from rims. Most of the wares are globular pots with lenticular bases. The other forms are scarce as the globular pots with symmetrical flat handles, with or without spout. The spouts do not present a sealing bead on the internal surface which is particular to this site. There are also a few bowls and one bottle. The vast majority of the pottery has not received any surface treatment. Only a few fragments have been decorated with lines of ferruginous paint. Another characteristic of the production of Visé is the use of clay with fine to very coarse inclusions of quartz (transparent and milky) and red or black grains. Thin yellow lenses may also be present in the clay matrix which colors vary from white to orange and gray if the sherds are overfired. Typological comparisons suggest that this material can be dated around the middle of the tenth century (de Longueville 2009). (Figs. 2 and 3e and f).

Gérin In Condroz, in the South of Namur, and on the western side of the Meuse river ( $\left.50^{\circ} 14^{\prime} 40^{\prime \prime} \mathrm{N}, 4^{\circ} 49^{\prime} 03^{\prime \prime} \mathrm{E}\right)$, Gérin is located (Fig. 1); the location is known for the exploitation of its plastic clays until the last century. A medieval waste pit was discovered there (de Longueville and Verbeek 2010). Its blackish filling was loaded with charcoal and fired clay nodules that can be assimilated to fragments of kiln's walls.

Three hundred eighty-four ceramic sherds coming from production wastes were discovered among which 64 different rims. The typological study reveals a predominance of 
Fig. 3 Macroscopic view. a and $\mathbf{b}$ Sherds from Ohey. $\mathbf{c}$ and $\mathbf{d}$ Sherds from Haillot. e and $\mathbf{f}$ Sherds from Visé. $\mathbf{g}$ and $\mathbf{h}$ Sherds from Gérin
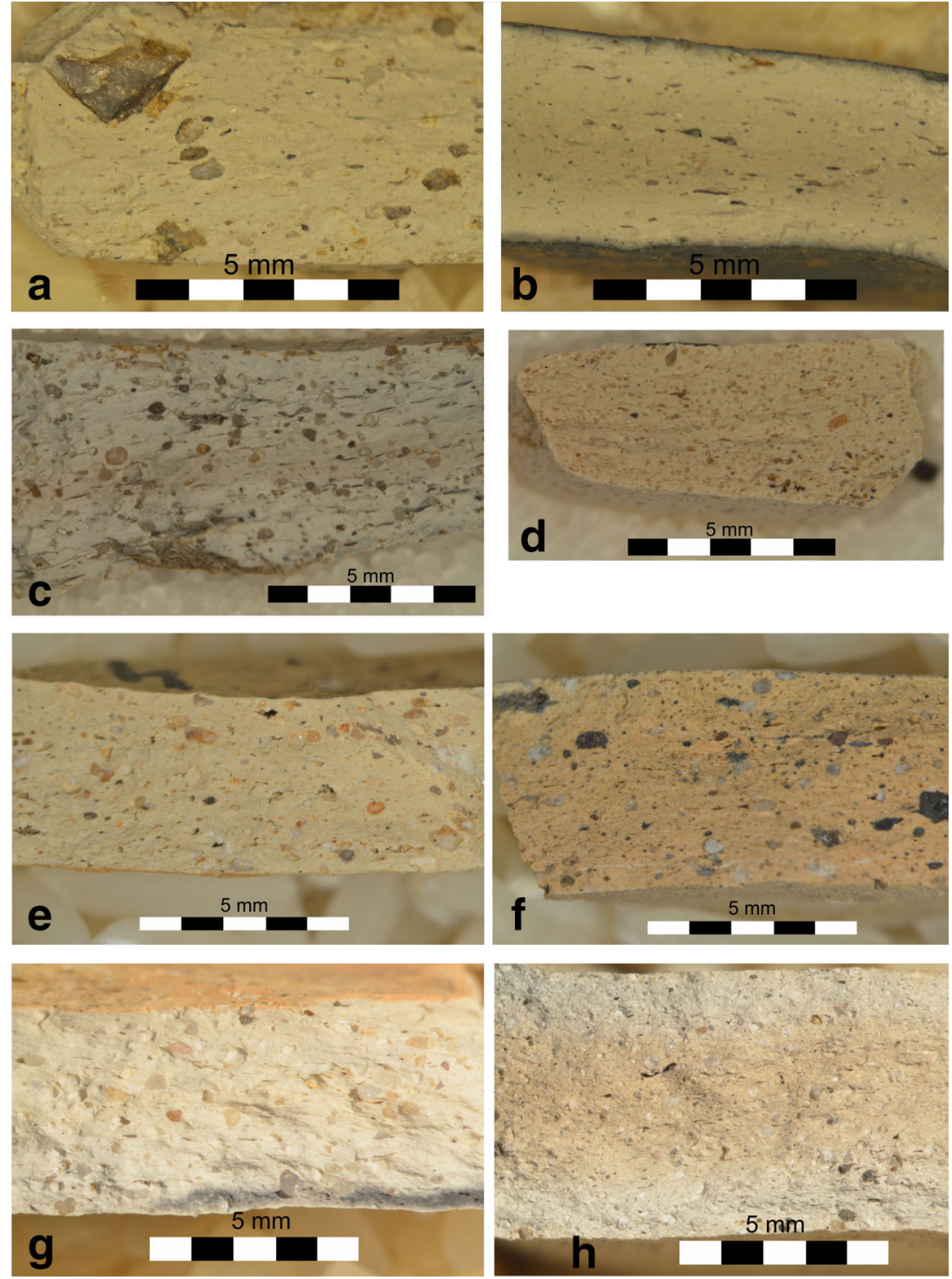

globular pots with flat or slightly lenticular bases. These pots may have a tubular spout which is inserted through the inside of the vessel as it is always done in this region. Some bowls were also part of the assemblage. The upper part of the globular pots is frequently decorated with rouletting (geometric pattern), the main decorative element on the ceramics of this site. The quality of printing is always rather mediocre: erased, misaligned, or superimposed patterns in the range of triangles and lozenge bands. Only one sherd is decorated with a pin forming vertical wavy lines. The fine matrix clays are white, pinkish to light orange, or light gray (depending on the firing atmosphere) with medium size quartz and some iron oxides. Typological comparisons suggest a dating during the second half of the tenth century (de Longueville and Verbeek 2010) (Figs. 2 and $3 g$ and $h$ ).

\section{Samples}

From the Merovingian site of Ohey, 10 white sherds were selected for petrography. Four were fine wares and 6 coarse wares among which 2 had a smoked surface. Five of them were analyzed by LA-ICP-MS and 3 were then analyzed by XRD.

Nineteen sherds from the Carolingian production site of Haillot were turned into thin sections, as well as one fragment coming from the wall of a kiln. All of them were chemically characterized. A piece of raw clay coming from the pit described above was also analyzed by LA-ICP-MS. The pottery sherds come from the different kilns of Haillot and they have different forms and macroscopic characteristics. Three potsherds have been analyzed by XDR. 
From Visé, production place of the Carolingian period, 15 sherds were selected for petrographical studies. For this particular site, we tried to choose different firing levels from poorly fired white sherds to overfired dark gray discard. Seven of them were then analyzed by LA-ICP-MS. Three sherds were analyzed by XRD. Here, also according to the macroscopic observations, we selected sherds with different degrees of firing.

Eleven samples from the Carolingian production site of Gérin were turned into thin sections, among which 3 light oranges, 1 light gray, and 5 whitish ones. Two kilns fragments were also chosen for analyses. For the chemical exams, we kept the 5 whitish sherds and the 2 kilns fragments. Three potsherds were then selected for XRD analyses.

\section{Methods}

As summarized by Fowler et al. (2019), petrographic and chemical analysis of pottery does not have to be opposed as analytical methods. They can rather complement each other in order to improve the comprehension of the materials and techniques. Petrography concerns the clay matrix and its nonplastic inclusions, both the ones occurring naturally in the clay and possible temper added. Petrography allows us to characterize the material from different sites by identifying the inclusions, their size, morphology, and distribution in the clay (Quinn 2013). This allows comparison in order to assess if the potters had the same supply or resources and used similar techniques. Chemical analyses characterize the material and eventually show if a particular treatment was performed on the clay (Fowler et al. 2019). In this paper, the main aim is to give social meaning to geochemical data (Arnold 2000, 2006) by understanding how early medieval artisans selected and used the resources at their disposal in the Mosan region and by retracing changes of practices and knowledge over a halfcentury.

Fifty-six sherds were made into thin sections. As much as possible, the samples have been taken on identifiable forms (rims or sherds related to rims) that can be linked to the typochronologies. The petrographic analyses were made on a Leica polarized light petrographic microscope at the division of Geology of the KU Leuven. Quantifications were done by image analyses with the imagJ 64 program.

In order to further characterize the clay samples, elemental analyses were performed on 40 sherds at the Field Museum in Chicago (Table 1 and Table 2 in Supplementary Material). Not only the suitability of LA-ICP-MS for the analysis of ceramic is well established now (e.g., Dussubieux et al. 2007; Golitko and Dussubieux 2016) but also other Andenne productions were analyzed at the Field Museum with the same method. In the same laboratory, Goemaere also analyzed raw clays from several clay mines of the Mosan region. These analyses are not published yet but our aim is to use the very same method in order to have more accurate comparisons of the clay on a longer time scale. In the near future and thanks to the work of Goemaere, this will allow to retrace the clay supply and pottery traditions in the long term.

Chemical analyses were carried out at the Elemental Analysis Facility at The Field Museum with a Thermo ICAP-Q ICP-MS connected to a New Wave UP213 laser for direct introduction of solid samples. The protocol was adapted from Dussubieux et al. (2007). The parameters of the ICP-MS are optimized to ensure a stable signal with a maximum intensity over the full range of masses of the elements and to minimize oxides and double ionized species formation $\left(\mathrm{XO}^{+} / \mathrm{X}^{+}\right.$ and $\mathrm{X}^{++} / \mathrm{X}^{+}<1$ to $2 \%$ ). For that purpose, the flow of argon, the radiofrequency power, the torch position, the lenses, the mirror, and the detector voltages are adjusted using an autooptimization procedure. No sample preparation is required. Fresh cuts were available for all the sherds and any surface contamination or diagenesis of the sample was eliminated by a pre-ablation of $\sim 20 \mathrm{~s}$.

For better sensitivity, helium is used as the gas carrier in the laser. Laser ablation choice parameters not only influence the sensitivity of the method and the reproducibility of the measurements but also the amount of damage to the sample. To determine elements with concentrations in the range of parts per million while leaving surface traces invisible to the naked eye, we use the single-point analysis mode with a laser beam diameter of $100 \mu \mathrm{m}$, operating at $80 \%$ of the laser energy $(0.2 \mathrm{~mJ})$ and at a pulse frequency of $20 \mathrm{~Hz}$. A pre-ablation time of $20 \mathrm{~s}$ is set in order, first, to eliminate the transient part of the signal and, second, to be sure that possible surface contamination does not affect the results of the analysis. For each ceramic sample, the average of 10 measurements of 57 elements, corrected from the blank, was considered for the calculation of concentrations (Table 1 and Table 2 in Supplementary Material). "Abnormal" measurements, resulting in high relative standard deviations that could result from the ablation of temper grains or from any other heterogeneity in the ceramic fabric under the sample surface are eliminated before calculations. Any contribution from the temper that may subsist will appear in the composition causing a dilution effect of the clay composition that can be corrected using a dilution correction (Harbottle 1976; Mommsen 2007). The relatively large number of measurements ensures that a representative volume of material is sampled despite the heterogeneity of the ceramic paste.

To improve the reproducibility of measurements, the use of an internal standard is required to correct possible instrumental drifts or changes in the ablation efficiency. The element chosen as internal standard must be present in relatively high concentration, so its measurement is as accurate as possible. To obtain absolute concentrations for the analyzed elements, the concentration of the internal standard must be known. To 
calculate the concentration of the internal standard and of the other elements in the samples, the calculation method described by Gratuze (1999) is used. This approach assumes that the sum of the oxide concentrations of the major elements, including the internal standard, is equal to $100 \%$ of the constituents in the samples. The isotope ${ }^{29} \mathrm{Si}$ was used for internal standardization.

Fully quantitative analyses are possible by using external standards. To prevent matrix effects, the composition of standards must be as close as possible to that of the samples. Two different standards manufactured by The National Institute for Standards and Technology are used to measure major, minor, and trace elements. SRM 610 is a soda-lime-silica glass doped with trace elements in the range of $500 \mathrm{ppm}$ (SRM 610). Certified values are available for a very limited number of elements. Concentrations from Pearce et al. (1997) are used for the other elements. SRM 679 is a clay used for a limited number of major and minor elements.

Many different techniques have been used in order to define the firing temperature, in particular, XRD analyses allowing to deduce a range of temperatures thanks to the presence and absence of some minerals (Tite 2008; Rasmussen et al. 2012). However, the sherds found on the production places correspond often to waster deposits. They could have been discarded because they were overfired or not well fired. So, from these, the interpretation of the analytical results and the determination of the firing temperature has to be careful. In order to have an accurate comprehension of the mastery of the firing process, analyses on raw material as on the large quantity of sherds should be done. These first results have to be taken with cautious, but they will give us an idea of the range of temperature reached the different kilns. In regard to our initial questions, they will be an additional characteristic to differentiate the Carolingian workshops and they will help us to consider the potential technical changes between the Carolingian and Merovingian periods.

Twelve of the analyzed samples were submitted to XRD analyses at the Department of Geology at Liege University. They were selected according to their chemical composition and their degree of firing determined by macroscopic observations. Kiln's walls were avoided as well as the sherds chemically different. In Visé, as these could be discriminated by macroscopic observations, sherds with different degrees of firing where selected.

The sherds of few milligrams were crushed in an agate mortar. The power held both the clay matrix and the inclusions. The powders were deposited without additional preparation on a zero background silicon sample holder. The holder has been inserted in a Bruker D8 ECO diffractometer, using the $\mathrm{CuK}_{\alpha}$ radiation $(\lambda=1.5418 \AA)$. The radiation was filtered with a Ni filter, in order to completely remove the $\mathrm{K}_{\beta}$ contribution. An angle between 2 and $70^{\circ} 2$ theta was scanned, with a step of $0.02^{\circ}$ and a counting time of $1 \mathrm{~s}$ per step.
The X-ray powder diffraction patterns were first interpreted using the EVA 3.2 software of Bruker (version 2014). This software allowed to identify the phases, by comparison with the ICDD database, version PDF-2 (Figs. 11, 12, 13, and 14). Then, the powder patterns were analyzed using the TOPAS 4.2 software of Bruker (version 2014), which allows a quantification of the mineral phases (see Table 4 in the Supplementary Material). The quantification procedure is based on the Rietveld method, which models the powder patterns starting from the crystal structure of the different phases. The errors on the final proportions are estimated around 5\%. Still, the amorphous phase could not be exactly quantified.

\section{Results}

\section{Petrography}

All samples from Ohey are made from the same clay that is beige to light gray. The thin sections can be subdivided into two clusters. The first set has a very homogeneous clay matrix (Fig. $4 \mathrm{a}$ and $\mathrm{b}$ ). The inclusions are mono-crystalline quartz grains, mica flakes, and iron oxides. Some dark clay nodules can also be seen. They represent less than $10 \%$ of the surface of the thin sections. There are two different classes of inclusions: one small (under $63 \mu \mathrm{m}$ ) and one that can be called medium (up to $200 \mu \mathrm{m}$ ). The smallest class is the majority. The inclusions are sub-angular and homogeneously distributed in the matrix.

The second group has a coarser paste (Fig. $4 \mathrm{c}$ and d). The clay matrix is quite thin and beige in color. The inclusions are quartz, mica flakes, and clay nodules as well as rocks fragments: chert, sandstone, and quartzite grains. They represent 10 to $15 \%$ of the matrix. The inclusions can be divided into three classes: small, medium, and large $(200-1 \mathrm{~mm})$. If the small and medium inclusions are quartz grains, iron oxides, and dark nodules of clay, the large elements are of more varied nature and include the rock fragments (chert, sandstone, and quartzite grains). The small inclusions are the most abundant. The medium and the large particles are sub-angular to subrounded. Their distribution in the clay matrix is not homogeneous.

In the samples from Haillot, the clay matrix is quite close to the one of Ohey. The nature of the inclusions is also quite similar: quartz grains, iron oxides, mica flakes, quartzite, and chert grains (Fig. 4e and f). Still, from the present sampling, no group can be separated and all the samples have close characteristics. The inclusions represent about 14 to $20 \%$ of the surface of the thin sections. They can be divided into two groups according to their size. The smallest $(5 \mu \mathrm{m}$-about $70 \mu \mathrm{m})$ are sub-angular to rounded and are homogeneously distributed. The largest $(100-300 \mu \mathrm{m})$ are more heterogeneous and their quantity 
Fig. 4 Micrographs of the potsherds. a Ohey 19 , xpl, first group, fine clay matrix with small inclusions of quartz (Qz), mica flakes (Mi), iron oxides (Ir). b Ohey 19, ppl, first group, clay nodule $(\mathrm{Cl})$, quartz $(\mathrm{Qz})$, elongated and oriented voids (Vd). c Ohey 5, xpl, second group, fine clay matrix with small medium and large inclusions of quartz (Qz), iron oxide (Ir), and quartzite (Q). d Ohey 5, ppl, second group, quartz (Qz), and small oriented voids (Vd). e Haillot 6, xpl, fine clay, quartz (Qz), and iron oxides (Ir). $\mathbf{f}$ Haillot 6, ppl, quartz (Qz), iron oxide (Ir), elongated and oriented voids (Vd). g Gérin 1, xpl, fine clay matrix with small and medium inclusions of quartz (Qz), iron oxides (Ir), and quartzites (Q). h Gérin 1, ppl, quartz (Qz), iron oxides (Ir), large, elongated and oriented voids (Vd). i Visé 35 , xpl, clay matrix with numerous small inclusions of quartz $(\mathrm{Qz})$, iron oxides (Ir), medium inclusions of quartz $(\mathrm{Qz})$. j Visé 35, ppl, quartz (Qz), dark nodules, elongated and oriented voids (Vd)
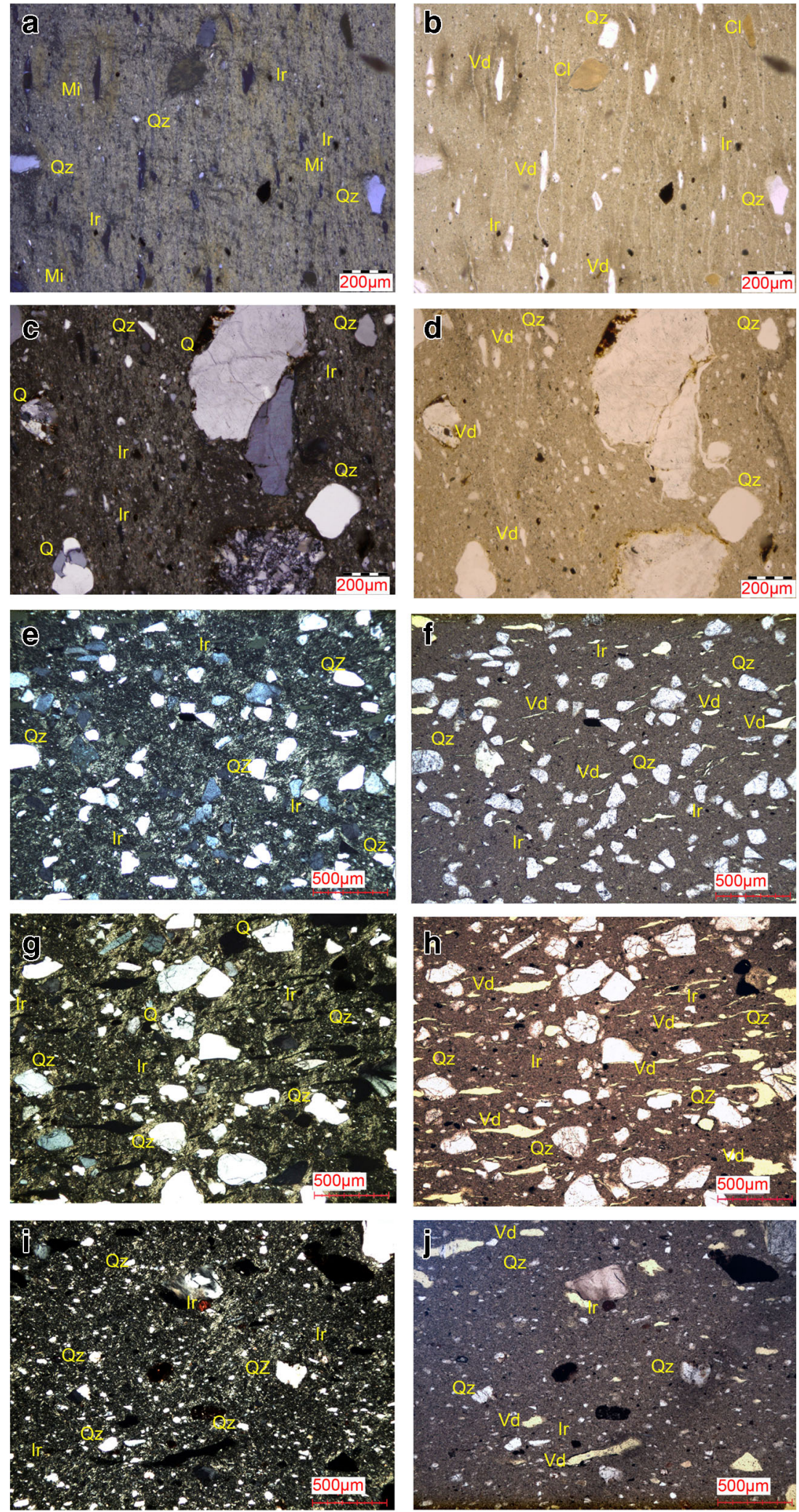

varies according to the sherd. Based on the aspect of the clay that seems more fused, Haillot 3 and 11 were probably fired at a higher degree than the other samples.
Between Gérin and Haillot, the petrographic differences are small. The clay matrix and the inclusions appear to be similar but the samples from Gérin are slightly more variable. 
The potsherds are made of a beige to gray clay matrix (Fig. $4 \mathrm{~g}$ and $\mathrm{h}$ ). The clay contains quartz grains and iron oxides. Mica flakes are quite rare. Quartzite and chert grains are also identified. The inclusions represent between 13 and $20 \%$ of the surface. The inclusions can be divided into two categories. The first $(5-50 \mu \mathrm{m})$ corresponds to quartz, iron oxides, and mica. They are subangular to rounded and their distribution is more or less homogeneous. The second category, quartz, quartzite, and chert, is larger (about $70-500 \mu \mathrm{m}$ ). They have an angular to rounded morphology and a more heterogeneous distribution. The quantity of the second category varies according to the sample. The only exception is Gérin 7 that contains clearly less inclusions (around $10 \%$ of the surface) and where the largest inclusions are scarce.

The clay of the samples from Visé appears brownish to gray. It contains mainly quartz inclusions. Mica flakes, iron oxides, and rocks fragments - quartzite, siltite, chert, sandstone, and micritic limestone - are also present. In some sherds (Visé 17, 18, 19, 38, 39, 46, and 48) dark rounded nodules could not be clearly identified. According to the image analyses of the particles, the inclusions represent between 11 and $22 \%$ of the total surface of the thin section (Fig. $4 \mathrm{i}$ and j). They can be divided into two classes according to their size. The small ones, less than $150 \mu \mathrm{m}$ (long), are the most abundant and their distribution in the clay matrix is homogeneous. They correspond mainly to quartz grains, mica flakes, and iron oxides that are rounded to sub-rounded. The large inclusions between 150 and $500 \mu \mathrm{m}$ in size are quartz, iron oxides, quartzite, sandstone, micritic limestone, and chert grains. They are heterogeneously distributed and angular to subrounded.

Three samples are coming from kilns. The clay matrix of the sample Gérin 14 is very different from the potsherds of this site. It is brownish and it contains a high quantity of small quartz, about $9 \%$ of the surface of the thin section (Fig. 5a and b). Some iron oxides can be distinguished but they remain limited in quantity. Most of the inclusions are between 10 and $50 \mu \mathrm{m}$ long. They are angular to sub-rounded and their distribution in the matrix is homogeneous. Also coming from a kiln, the sample Gérin 15 is made of a finer clay matrix containing less small quartz ( $8 \%$ of the total area) (Fig. $5 \mathrm{c}$ and d). It is quite close to the pottery samples and the distribution of the largest inclusions is not homogeneous. Gérin 14 and 15 are very different from each other. They are either from different parts of the kiln, from different construction phases, or from different structures. Haillot 5 is very close to the samples made of potsherds from the same site (Fig. 5e and f). It has the same clay matrix and identical inclusions, but the largest inclusions have a more heterogeneous distribution than in the pottery.

\section{Chemical analyses}

The results of the chemical analyses presented in Table 1 correspond to a mean of 10 punctual measurements of the clay matrix. They confirm some of the distinctions observed in petrography. Among the samples coming from the four sites, the principal component analysis including all the elements shows three groups (Fig. 6). A cluster contains the samples from Visé that are totally different from those of Haillot and Ohey constituting another group. The samples from Gérin plot in between. However, Gérin 7 is closer to the samples of Haillot and Gérin 14 to those of Visé. This distinction is confirmed by a principal component analysis based only on the rare earth elements (REE) (Fig. 7) showing that Gérin 7 and Gérin 14 are closer to the samples of Haillot. In this graph, the sample Haillot 26 is also distinguished from the other samples from the same site. Excluding the REE and the mobile elements in sedimentary context $(\mathrm{Na}, \mathrm{Mg}, \mathrm{P}, \mathrm{K}, \mathrm{Si}, \mathrm{Ca}, \mathrm{Mn}, \mathrm{Rb}$, $\mathrm{Sr}, \mathrm{Ba}$ ) from the analyses, the samples from each site are gathered (Fig. 8). Still, the same samples, Gérin 7 and Gérin 14 , appear to be distant from the group of Gérin. The group of Visé is clearly different from the other samples.

The samples from Visé contain more silica and less aluminum than the other ceramic sherds. They are also clearly richer in calcium, copper, and REE (Table 1). The distinctions made in the set of samples are due to the type of material used by the potters. The one from Visé probably contains less kaolinitic clay. The higher calcium content could be explained by the numerous limestone deposit in the environs which can be seen on the geological map (Forir 1896). Micritic limestone was also observed in the samples. Even if the $\mathrm{Cu}$ content is higher in Visé (Fig. 9) (min. 120 ppm for the samples of Visé versus $20 \mathrm{ppm}$ for the other samples), it stays at a relatively low content, not abnormal for clays. Its variation also illustrates the use of different raw materials.

The sherds from Gérin are close to those of Haillot and Ohey. Their alumina content is 1 or $2 \%$ lower (Fig. 10) and their proportion in REE is slightly higher than in Haillot and Ohey even if it stays under the one of Visé. The sherds from Gérin especially differ by a slightly higher iron, cobalt, nickel, and zinc contents (Fig. 9). These elements are also present in clay deposits in trace amounts in iron oxides/hydroxides and in non-clay, non-quartz minerals. The contents reported here are not unusual with respect to what could be considered background values for sedimentary clay beds (Degryse and Braekmans 2014).

Finally, the sherds of Haillot and Ohey are almost identical. The $\mathrm{Al}$ content is quite higher than in the other samples while the $\mathrm{Fe}$ or $\mathrm{K}$ are lower. Their clay matrix certainly contained more kaolinitic material. The only distinction that can be made between Haillot and Ohey is their titanium content that is higher in the samples of Ohey (Fig. 10). Titanium dioxide 
Fig. 5 Micrographs of the kilns fragments. a Gérin 14 , xpl, clay matrix with numerous small inclusions of quartz $(\mathrm{Qz})$, and iron oxides (Ir). b Gérin 14, ppl, quartz (Qz), and large voids (Vd), without orientation. c Gérin 15, $\mathrm{xpl}$, fine clay matrix with small and medium inclusions of quartz (Qz), iron oxides (Ir), and quartzites (Q). d Gérin 15, ppl, quartz (Qz), iron oxides (Ir), small and oriented voids (Vd). e Haillot 5 , xpl, fine clay matrix with quartz $(\mathrm{Qz})$, rock fragment $(\mathrm{R})$, and iron oxides (Ir). f Haillot 5, ppl, quartz $(\mathrm{Qz})$, rock fragment $(\mathrm{R})$ iron oxides (Ir), large voids (Vd)
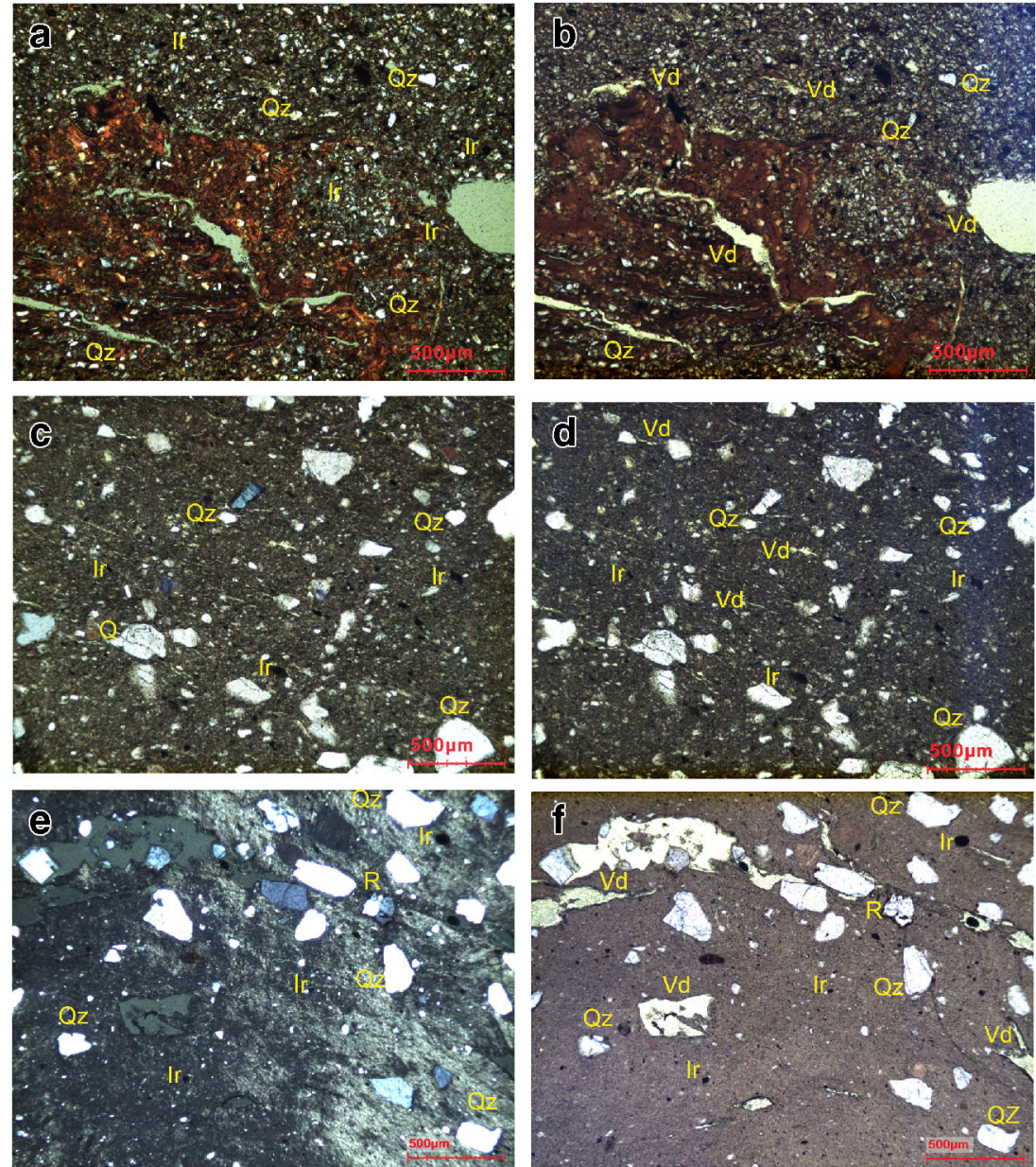

might be present in kaolinite between 0.2 and 2.5\% (Weaver 1976). In the cluster of Ohey, it is the only significant difference and no other element is distinctive from the sherds of Haillot. The cause of the difference between the samples of Haillot and Ohey remains unclear.

Among the whole samples, some sherds appear to be different. From macroscopic observations, Visé 38 seems to be the most highly fired sherd of this site. Its paste is the darkest and hardest. It is also completely deformed. From a chemical point of view, it has high $\mathrm{K}, \mathrm{Rb}$, and $\mathrm{Ba}$ values. For samples made of the same clay and baked at different temperatures, the concentrations of these elements do not vary (Cogswell et al. 1996). Still, for Visé 38, the time spent in the kiln by the sherd has to be considered. The increase in $\mathrm{K}, \mathrm{Rb}$, and $\mathrm{Ba}$ might be due to contamination by the fuel used. Gérin 14 corresponds to a kiln fragment. It has a high content of $\mathrm{Na}, \mathrm{Mg}, \mathrm{Mn}, \mathrm{Fe}$, $\mathrm{Zn}$, and $\mathrm{Pb}$ and the use of earth from the "upper levels", the use of soil, can be assumed, at least regarding the higher $\mathrm{Na}$, $\mathrm{Mg}, \mathrm{Mn}$, and Fe concentrations (Weil and Brady 2016). As shown by the principal component analyses, Gérin 7 also appears quite different from the set of the samples from the same site because it has a lower content in REE and it is clearly higher in $\mathrm{Ba}$. This sherd is also the only one painted in the set of Gérin and appears quite white. As seen in the thin sections, it might be made from a different material.

\section{XRD analyses}

Quartz, muscovite 2M1, rutile, anatase, gehlenite, mullite, orthoclase, hercynite, and cristobalite have been identified by XRD analyses (Fig. 11, 12, 13, and 14). It appeared that the percentage of the amorphous phase cannot be accurately evaluated. By consequence, the different minerals cannot be quantified with enough precision. Still, quartz is always the most abundant in every sample. Kaolinite is not attested and hematite is either absent or in too low quantity to be detected. Lime is detected in so low proportions that it is not worth to be considered.

The sherds from Gérin can be distinguished by the presence of gehlenite that is absent from the other samples (Fig. 11). These sherds also have rutile. Muscovite is identified in Gérin 2 and Gérin 3 has mullite.

Mullite is also present in all the samples from Ohey (Fig. 12) and Haillot (Fig. 13). Out of Haillot 28, they 
मू

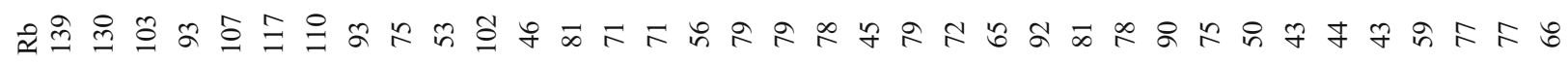

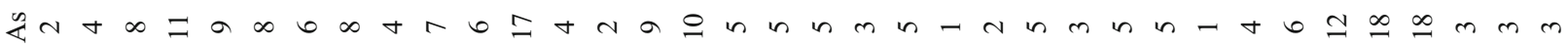
초유

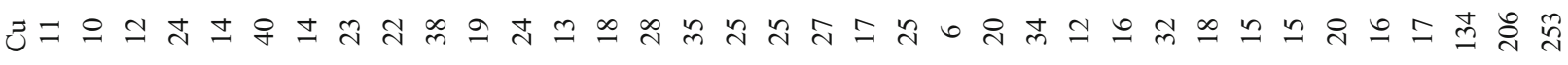
治旅

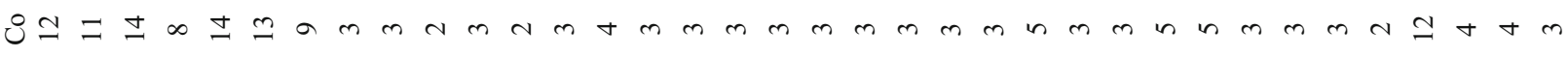

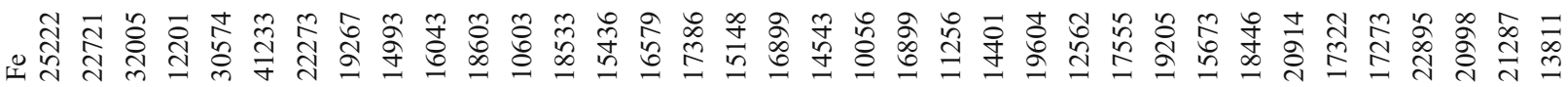

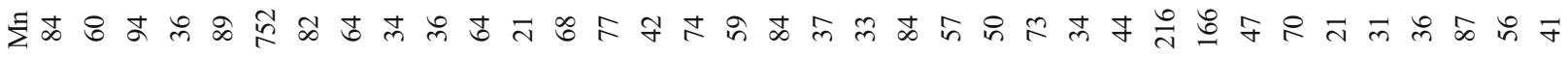

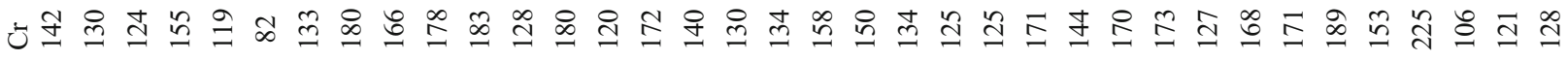

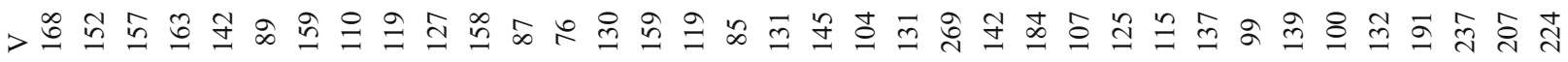

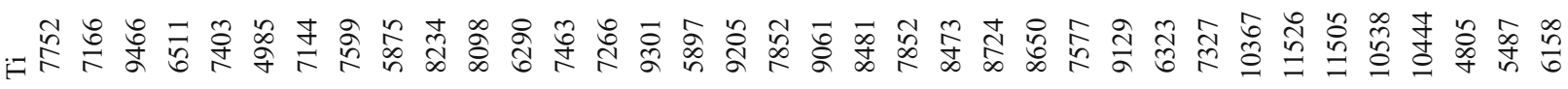
นัป ש

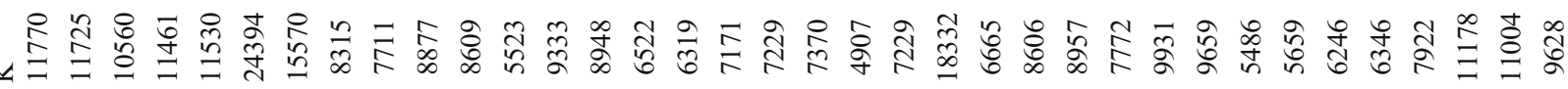

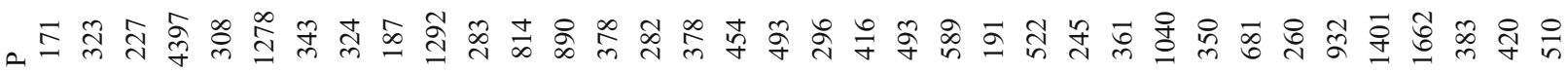

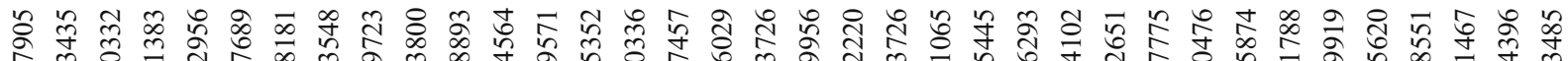

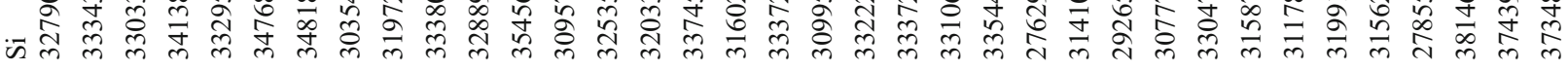

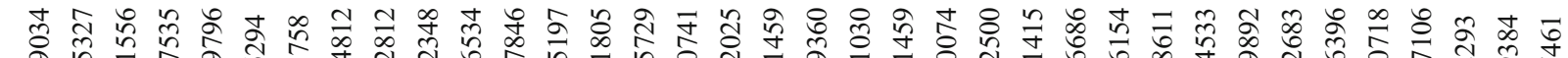

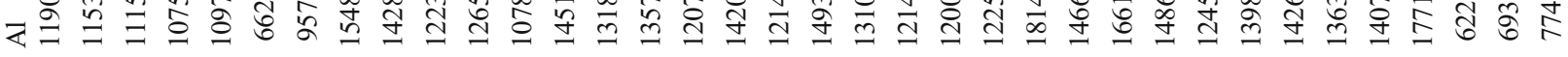

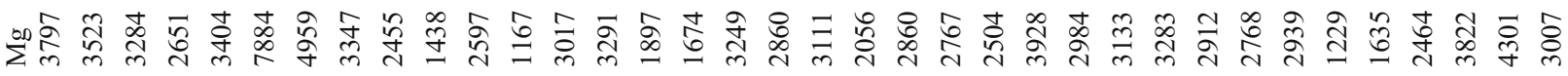

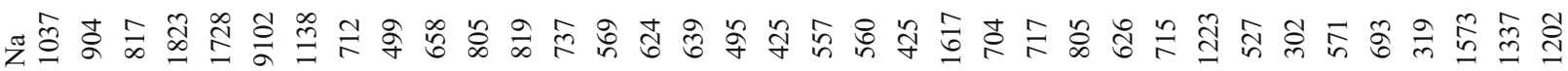
๓

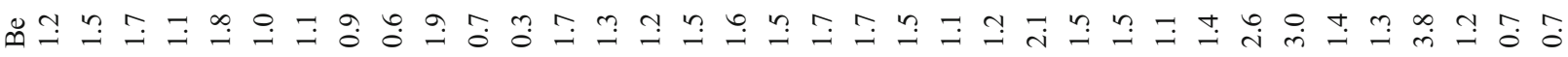

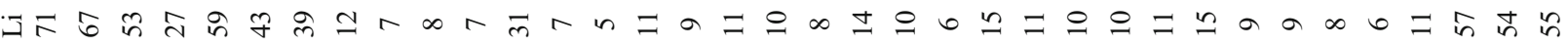

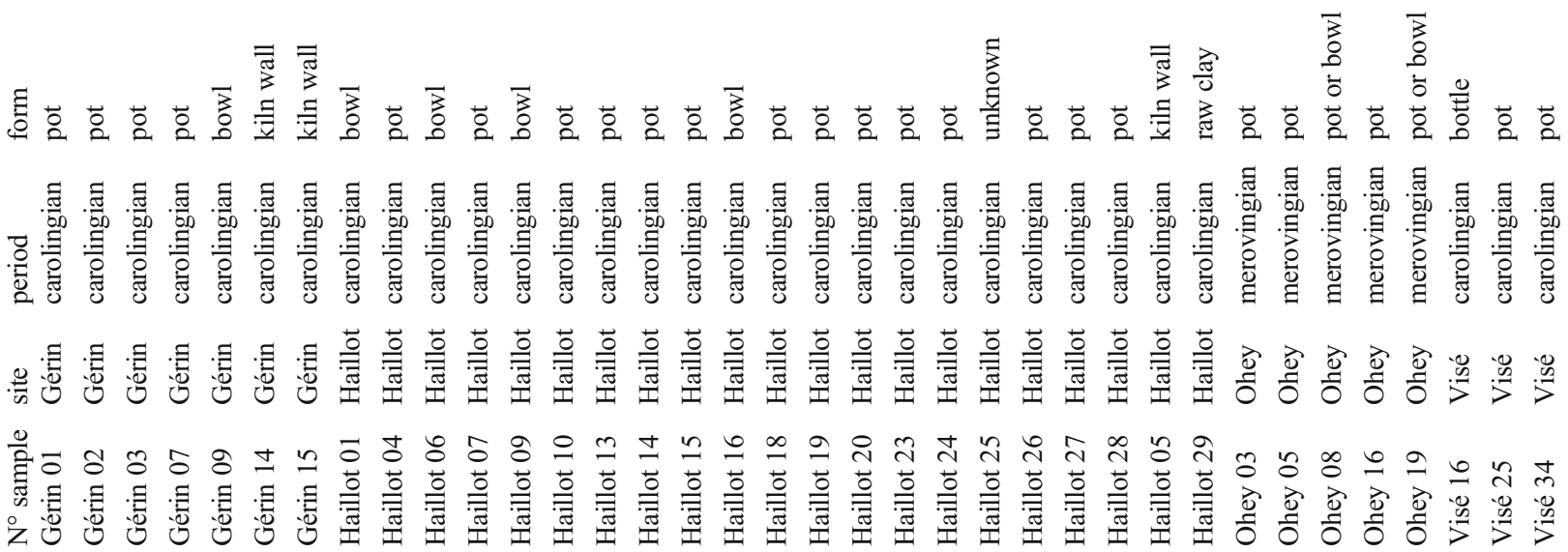




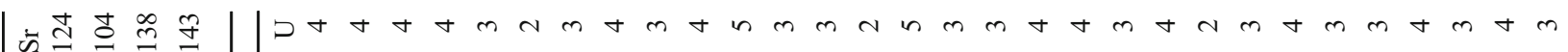

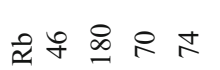
$\sum=r n$ F⿻コ一ำ约 종

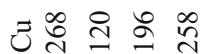

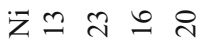
in in $m$ a

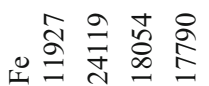

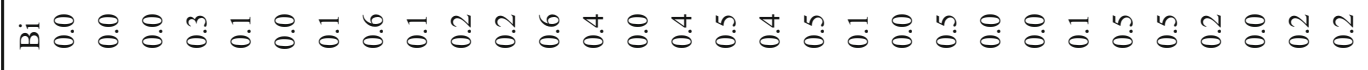

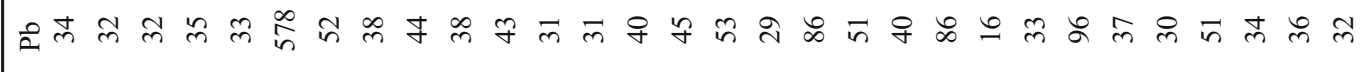

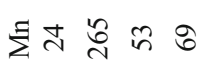

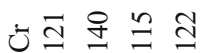

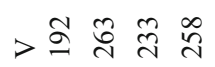

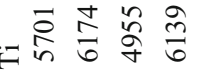
นัป ปัป ป

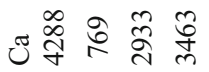
年先

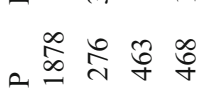
ปิ

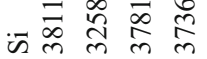

늉 苦早

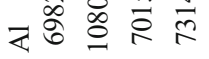

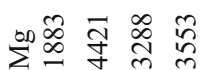
艺孚 \&

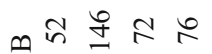

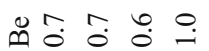

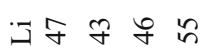

言莒 $\stackrel{\circ}{\circ} \stackrel{\circ}{\circ}$

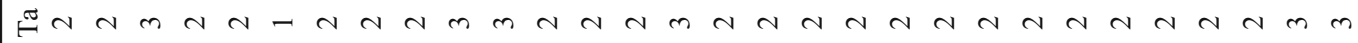

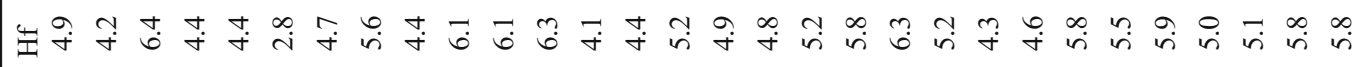

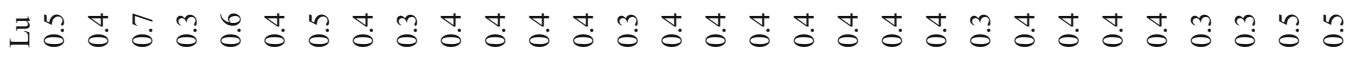

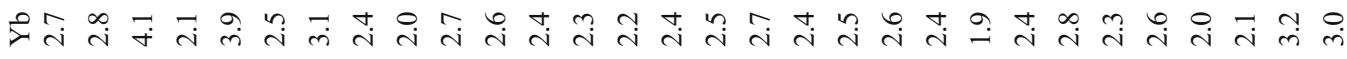

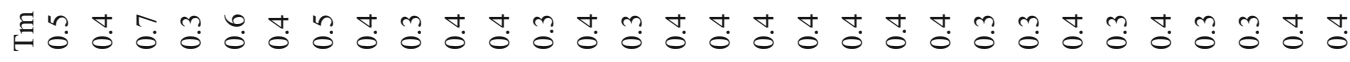
牙 䝅

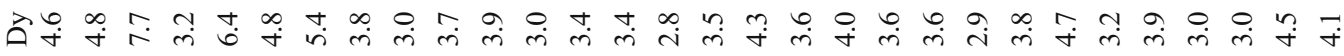

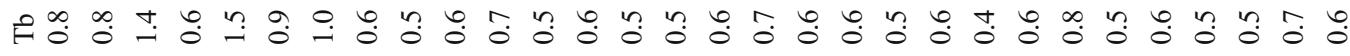

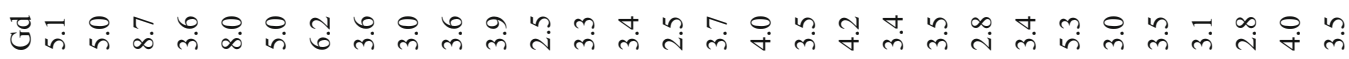
馬去先

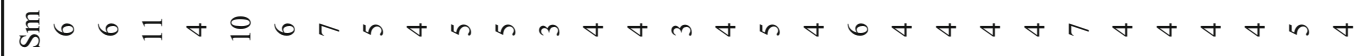

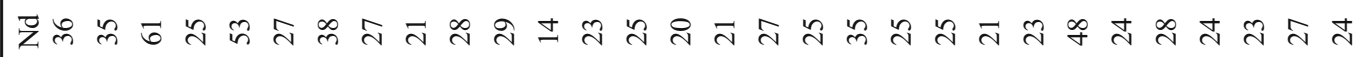

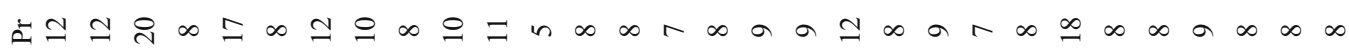

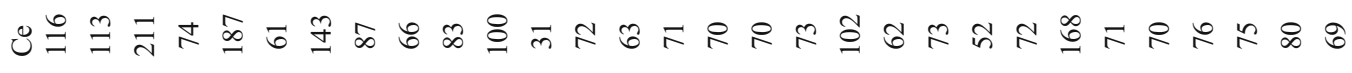
편

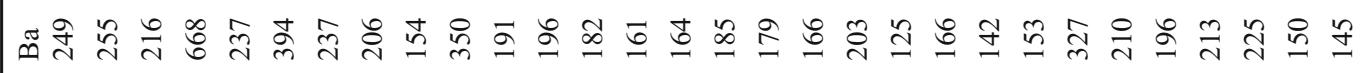

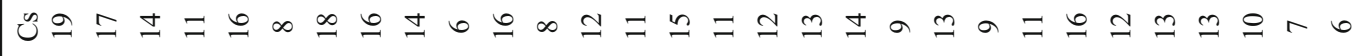

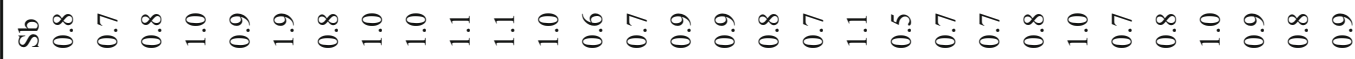

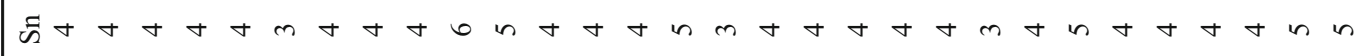

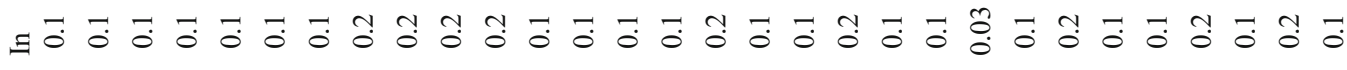

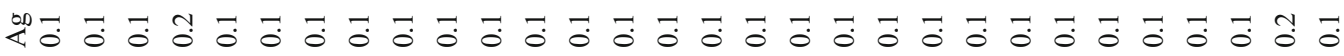

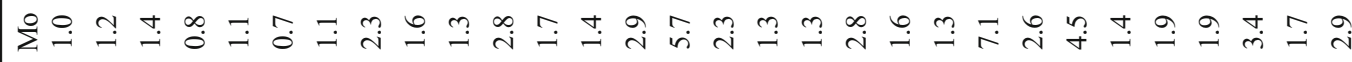

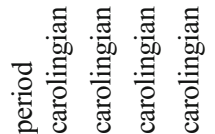

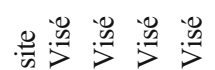

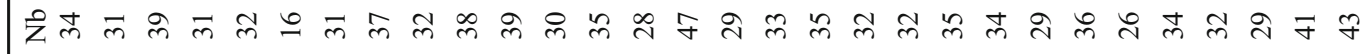

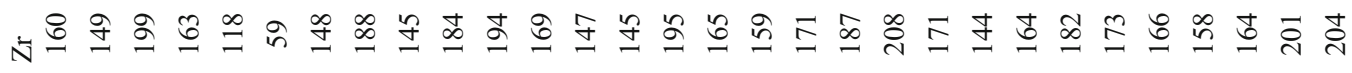

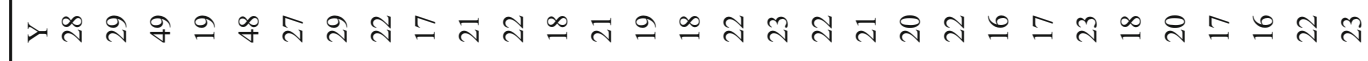

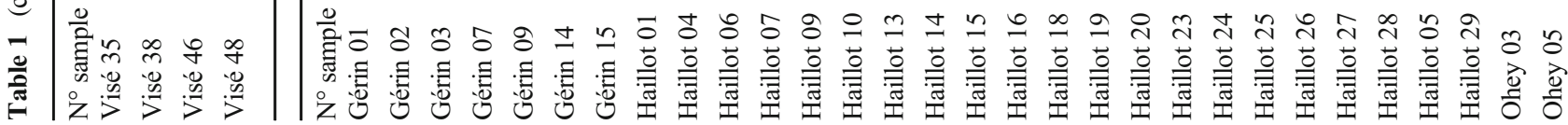




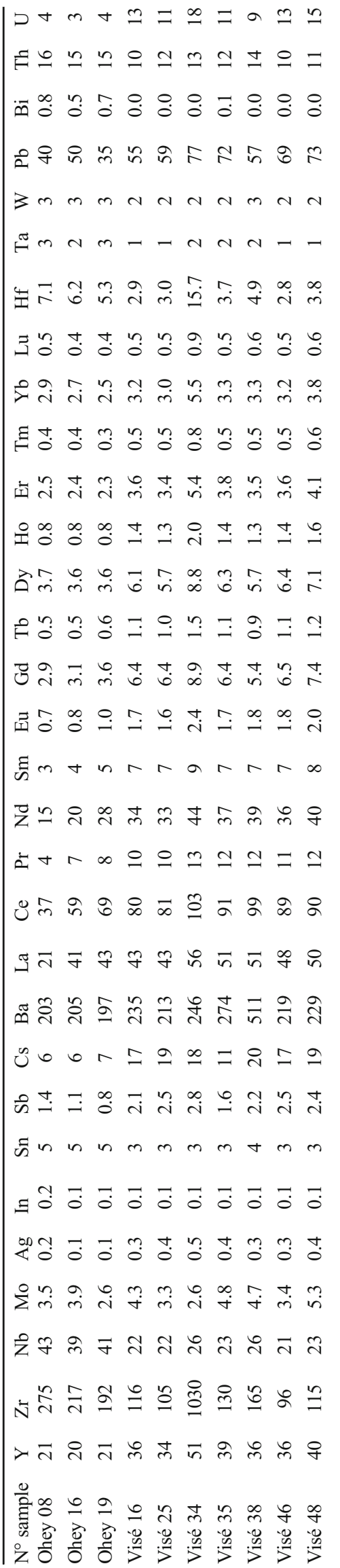

also have anatase. Rutile is absent from the sherds of Haillot but it is attested in the samples from Ohey. In this set, Ohey 19 is distinguished by a high content of muscovite that is also present in Haillot 28 and 29 but in lower proportions. The sherd Haillot 27 has orthoclase but in low quantity.

In the three samples from Visé, Visé 35 is clearly different (Fig. 14). It is the only sample of this set with no mullite and it has a quite high proportion of muscovite. Next to mullite and rutile, Visé 46 and 48 contain hercynite and cristobalite.

\section{Discussion}

If the petrographic variations are mainly due to the initial material used and its treatment (Arnold 1985; Tite 1999), the elements affecting the chemical variability of pottery can be due to the clay deposit chosen to supply the production; to the clay processing or the technique used to prepare and fire the clay; to the use of the ware and the matters that it contained; and finally, to its burials conditions (Arnold et al. 1991; Cogswell et al. 1996; Neff et al. 1988; Neff et al. 1989; Rye 1976; Stoltman et al. 2005; Fowler et al. 2019). The XRD results are due to several factors among which the composition of the raw clay and its inclusions, its crystal structure, the grain sizes involved, and the thermal treatment (Braekmans and Degryse 2016).

\section{Clay supply and processing}

Back to the topic at hand, the selection of the raw material is the first subject to be discussed. Here, the point is not to identify the exact provenance of the clay and the deposit that might have been used. Tracing it appears to be quite complicated and could be the subject of further researches (de Longueville and Challe 2016). In this paper, we would rather focus on the supply scheme of the artisans and see how it varied through time. Regarding procurement strategies, five different potters' behaviors are distinguished (Bishop et al. 1982):

- Potters who use many clays and show no preference for a particular one (non-discriminating strategy).

- Potters who prefer on a single source of clay for all the vessel types they made (discriminating strategy).

- Potters who use two or several sources for different types of pottery (specializing strategy).

- Potters who mix clay from different sources (compounding strategy).

- Potters who use clay from distant sources (importing strategy).

Clay deposits are attested around the sites concerned by this study (Goemaere 2017; Goemaere and Quinif 2010). The inclusions identified by petrography are also all attested 
Fig. 6 Principal component analysis with all samples regarding all the elements obtained by chemistry

Fig. 7 Principal component analysis with all samples regarding rare earth elements obtained by chemistry
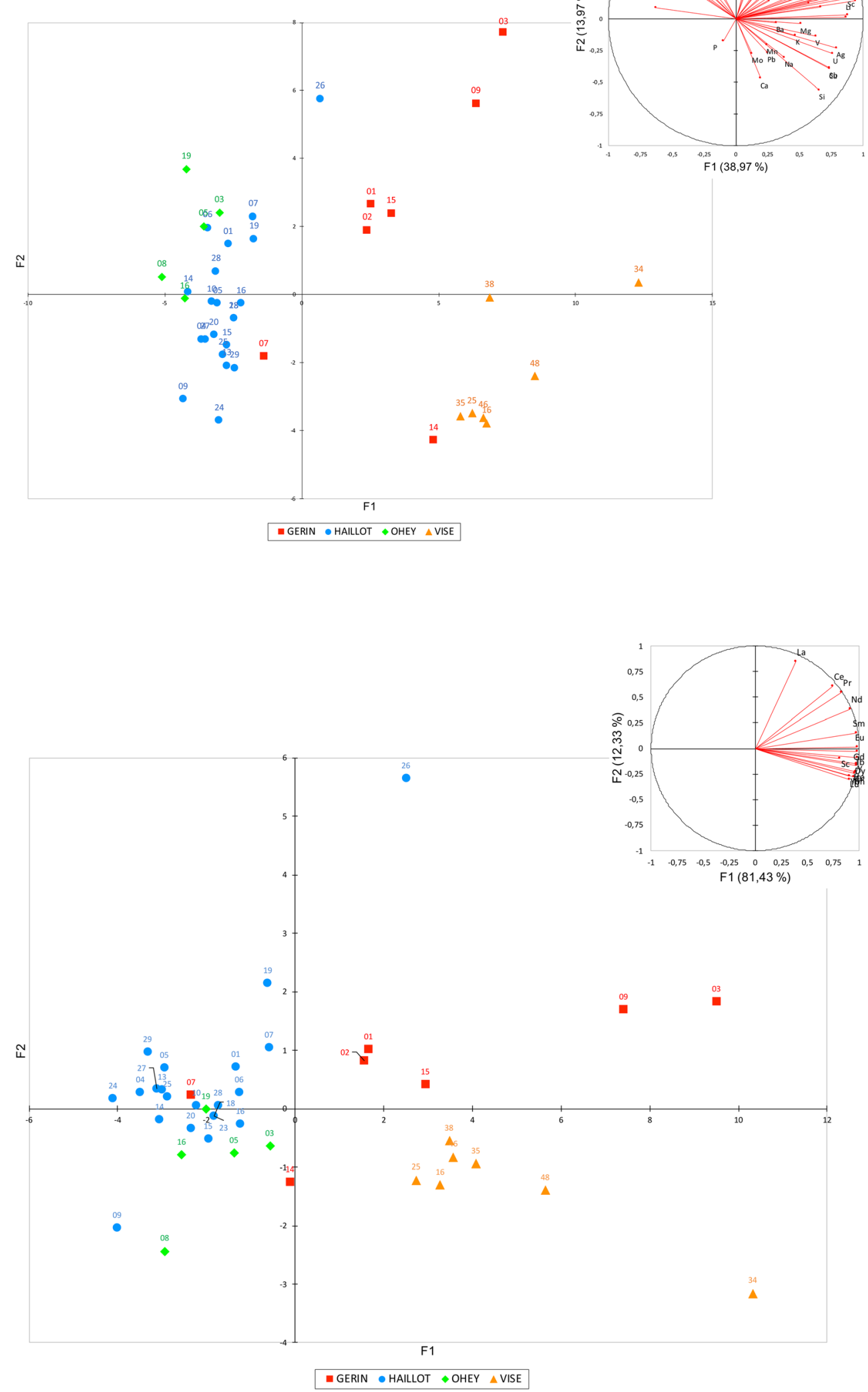
Fig. 8 Principal component analysis with all samples excluding rare earth elements and mobile elements obtained by chemistry

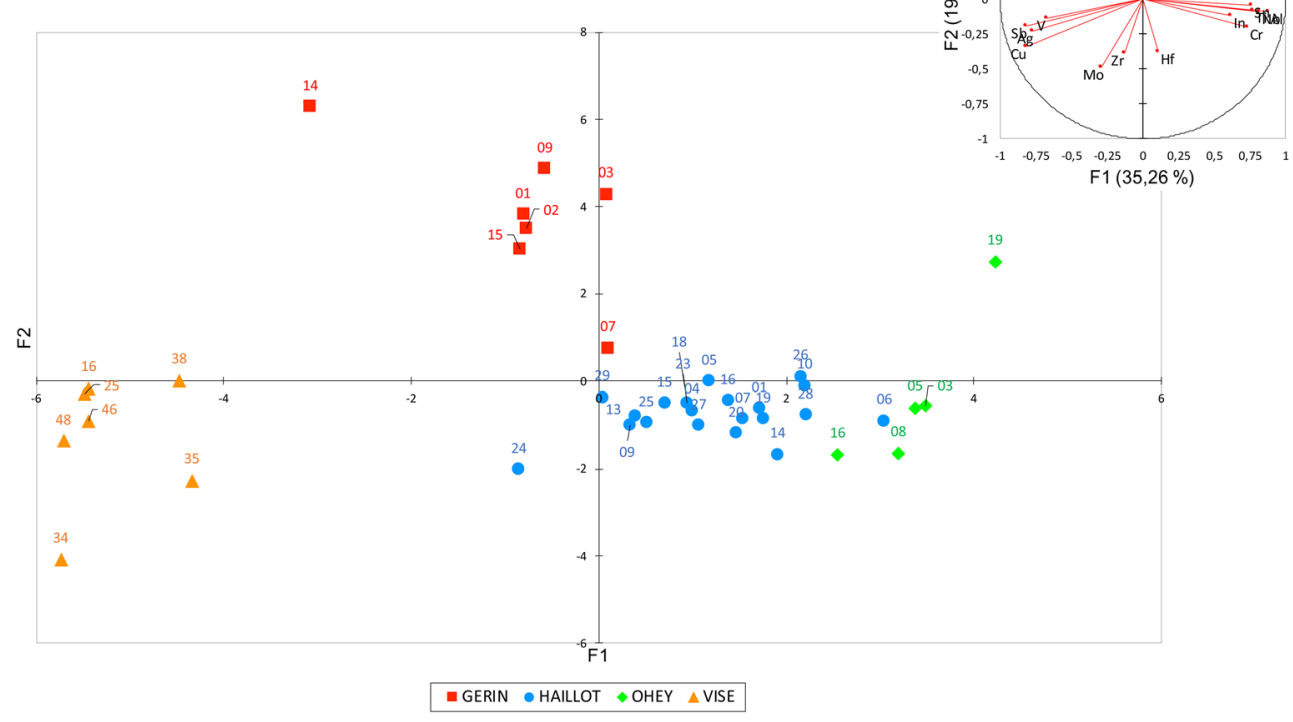

in the region. Potters used close types of clay in Ohey, Haillot, and Gérin but the deposits were different as shown by the variations of chemical results and the crystalline materials. Thus, it seems improbable that the materials were imported over long distances and the potters certainly used the plastic earth available locally.

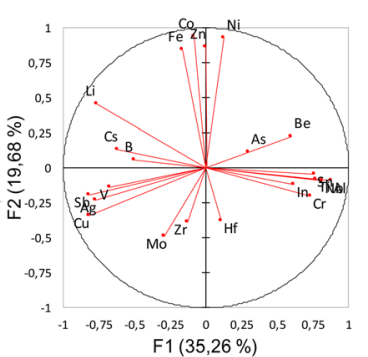

Looking at the sherds, it seems obvious that the Carolingian potters wanted a white or cream paste with inclusions of a certain size. For the three productions, no major difference in clay material used in each workshop was observed with petrography. Looking at the chemical compositions, outside the particular sherds mentioned above, the
Fig. 9 Bivariate plots $\mathrm{Cu}$ versus $\mathrm{Ni}$

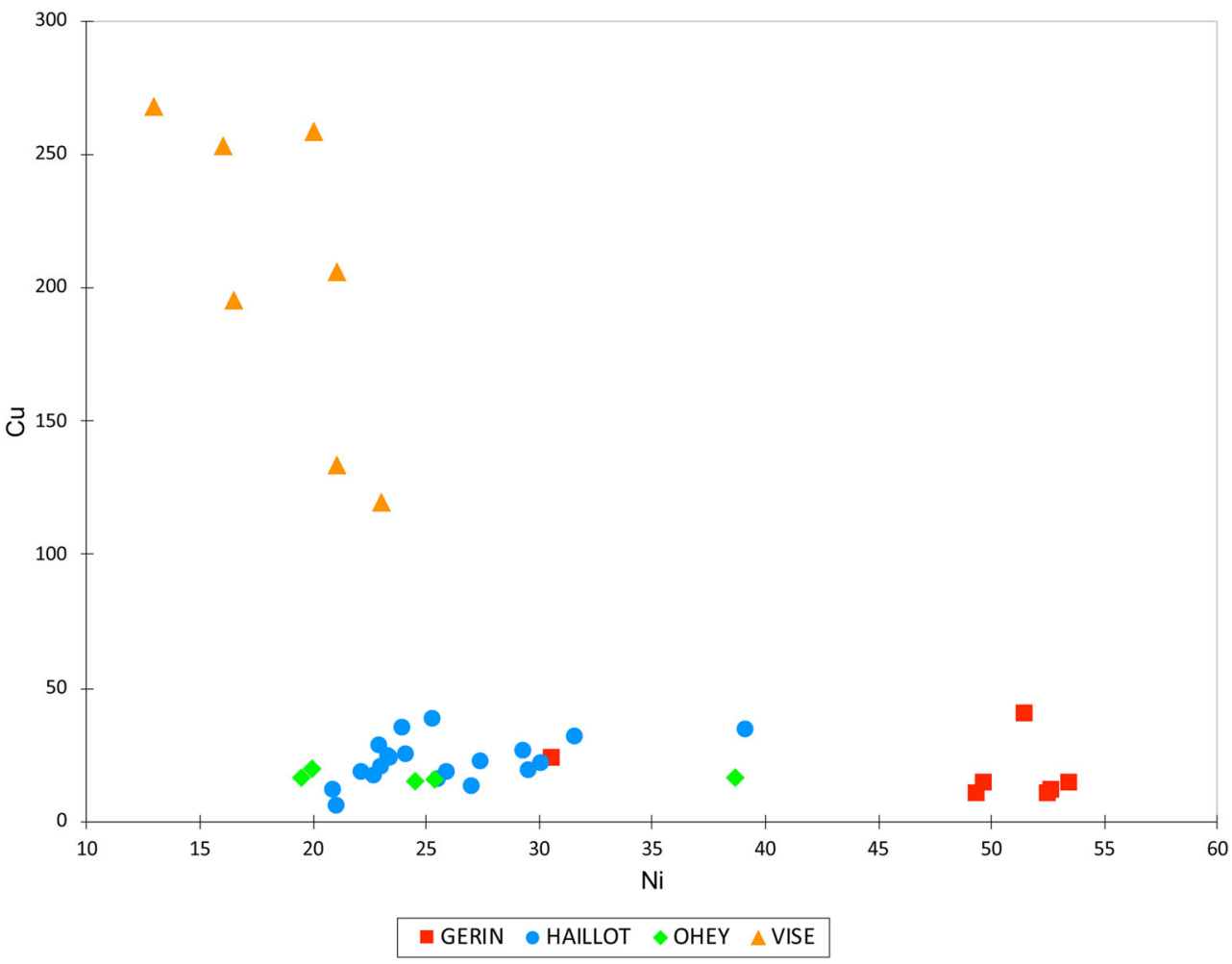


Fig. 10 Bivariate plots Ti versus $\mathrm{Al}, R^{2}=0.4662$

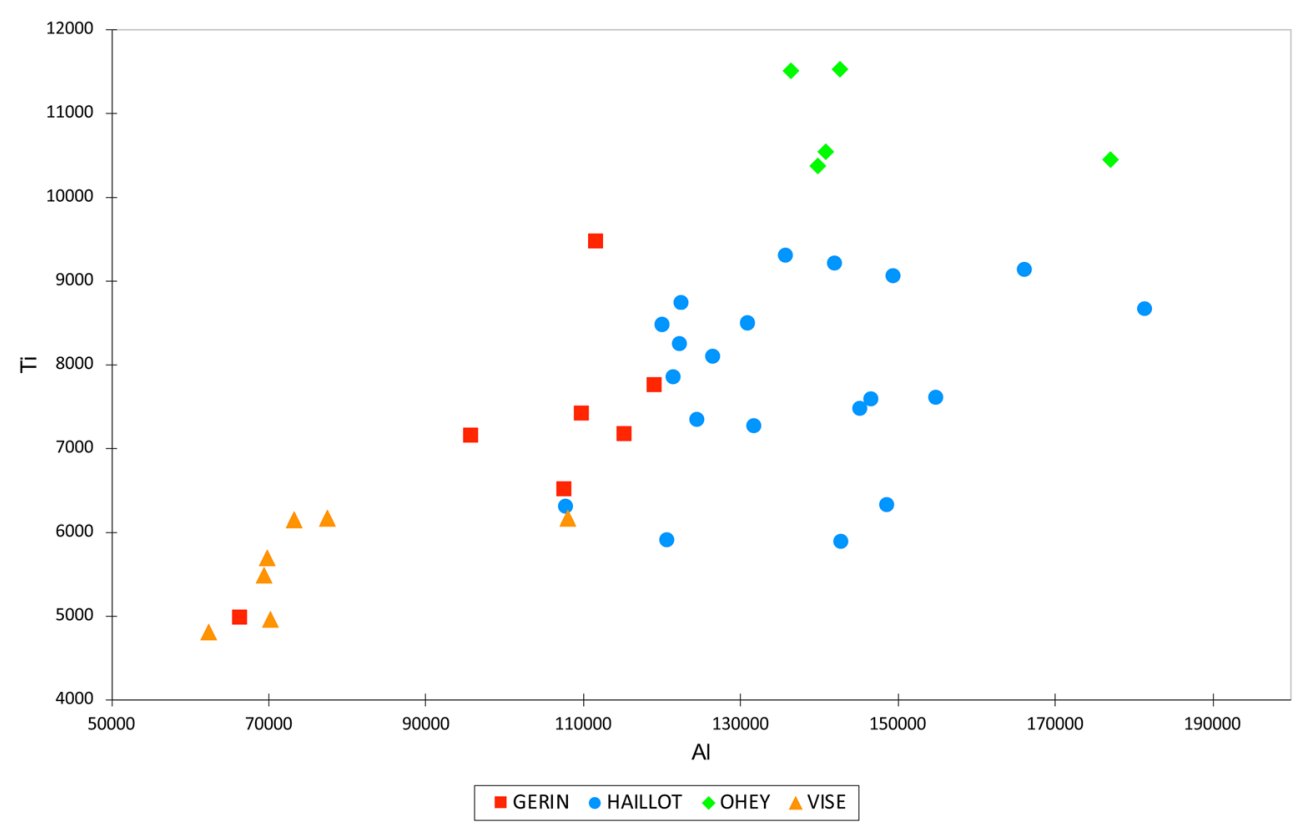

results are quite homogeneous for each production. The variability is probably caused by minor chemical variations in clay deposits, rather than by a real change in the supply strategy. Therefore, we can infer that Carolingian potters of each workshop had one preferred source of material for all the production and that they applied a discriminating strategy. The potters selected a whitish material with certain properties and they could identify it in their environment.

Regarding the Merovingian potters who made the white pottery found in Ohey, the differences observed with petrography are directly related to the type of pottery: the cooking pots have a paste with bigger inclusions while the beakers and bowls have a paste with smaller inclusions. The whole set being chemically very homogeneous, it is likely one single clay was selected and then prepared in order to obtain the required texture. On the other hand, the white pottery was quite rare during the Merovingian period. On several sherds found in Ohey, the surface was gray or brown because the potters wanted to obtain dark products that were common for the period. A white surface mainly occurs in cooking pots. The site of Ohey and its region are surrounded by kaolinitic clay deposits (Goemaere 2017; Goemaere and Quinif 2010) and the potters most probably used the material that they had at their disposal. The plastic earth was not used for its quality and it was not specifically selected for its color. So, the potters furnishing the site of Ohey likely took the clay resources available most nearby, as in the other Merovingian workshops (Van Wersch et al. 2015). By consequence, these artisans seem to have a non-discriminating strategy and they adapt the techniques to the products they wanted to obtain.
Fig. 11 Diffractograms of the samples from Gérin ( $\mathrm{y}=$ counts square roots). The PDF reference corresponds to the powder diffraction file in the ICDD database

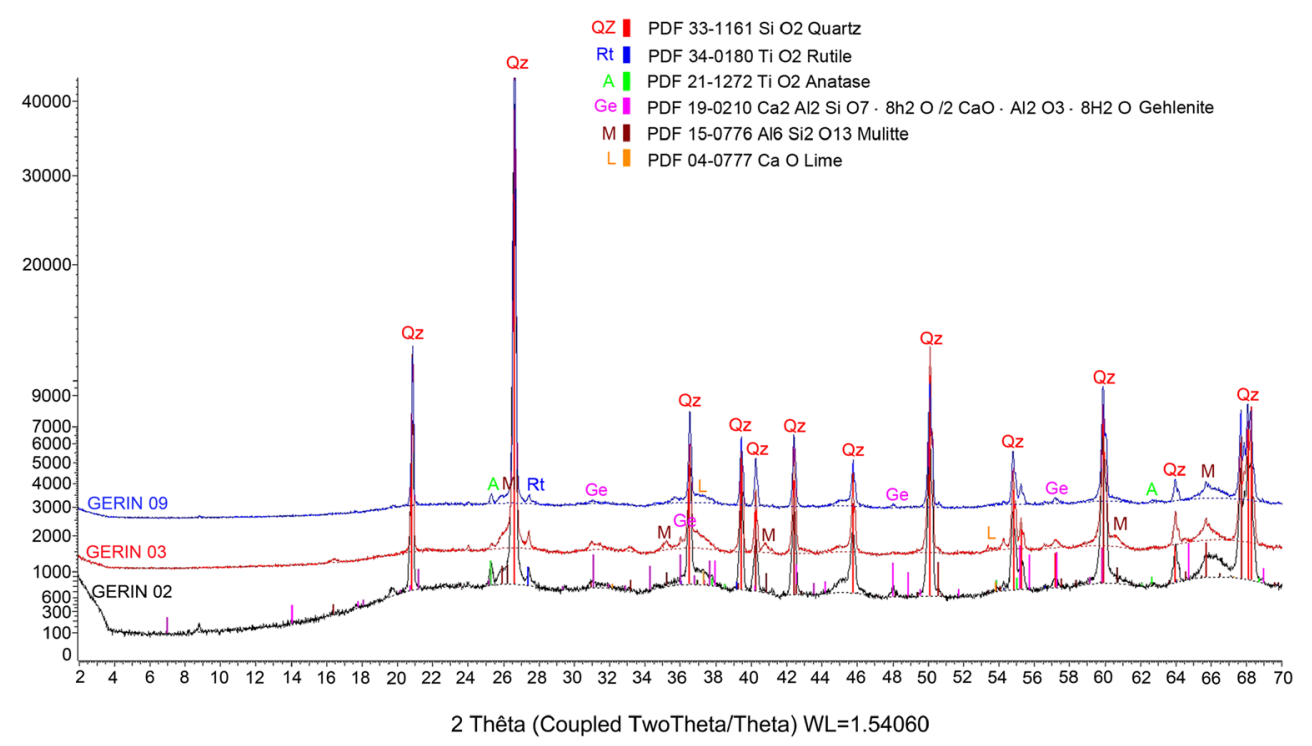


Fig. 12 Diffractograms of the samples from Ohey $(\mathrm{y}=$ counts square roots). The PDF reference corresponds to the powder diffraction file in the ICDD database

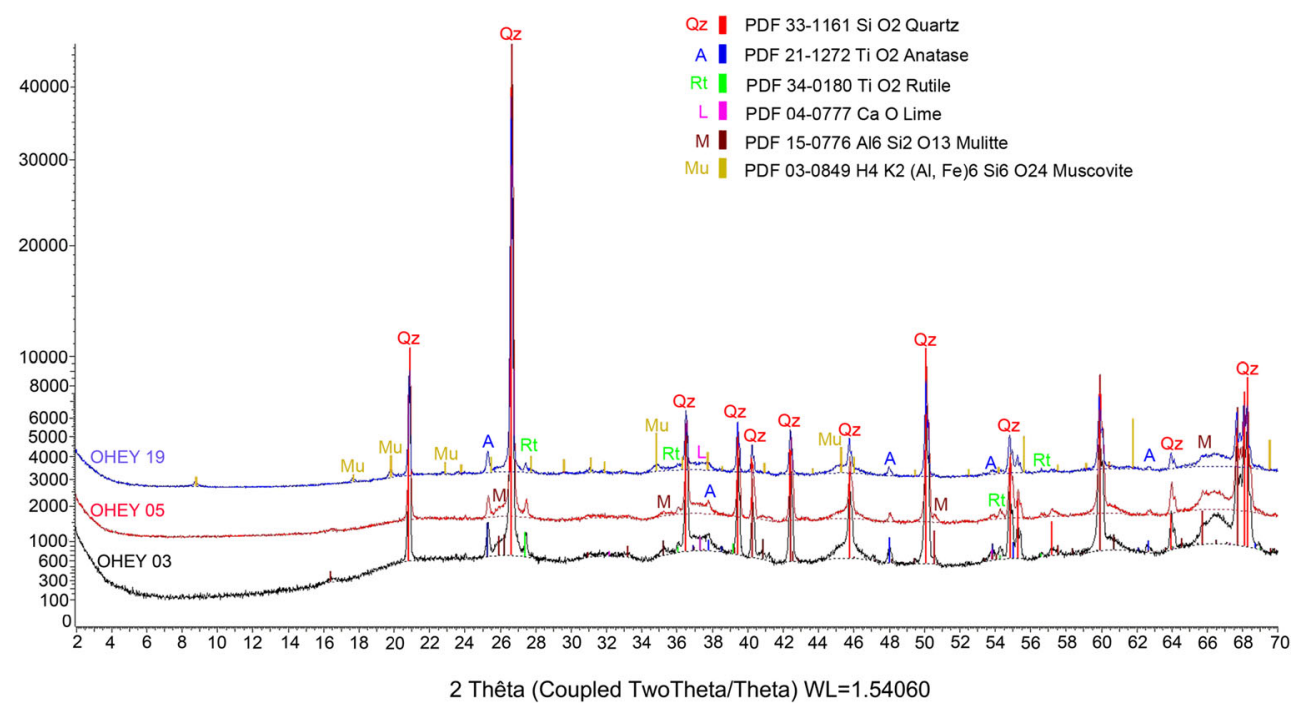

Once the clay is extracted, it has to be processed. Between Merovingian and Carolingian periods, a first technical difference can be seen in the homogenization process. Due to the heterogeneous distributions of the large inclusions in Merovingian pottery, the homogenization of the clay matrix was probably basic. In comparison, the distribution of the non-plastic inclusions in the clay matrix of the Carolingian pottery is more homogeneous and this is probably due to a more careful mixing of the material meant for pottery making. Indeed, in the thin section made from the kilns remains, especially sample Haillot 5 , the distribution of the second class of inclusions is more heterogeneous than in the potsherd, probably because this was less important for the kiln's properties than for the pottery.

Regarding the size of the inclusions, the Merovingian potters made two different types of paste: one corresponding to the cooking pots with a clay matrix containing three different sizes of inclusions and the second corresponding to the vessels with a clay matrix containing only two sizes of inclusions and avoiding the big ones. These craftsmen used the same raw clay for the two types of paste, as proven for other regions (Châtelet et al. 2005; Van Wersch et al. 2015). In the Carolingian pottery, small differences can be seen but they are not linked to the shape of the wares and, globally, at this stage, all the sherds can be classified in one group. The Carolingian paste is coarser than the fine Merovingian paste used for the vessel but it is finer than the coarse paste of the cooking pots. One of the reasons explaining this change might be that the potters realized that the kaolinitic clay could support the temperatures and mechanic shocks linked to the use of pottery as cooking pots (Desbat and Schimtt 2003) and that the addition of large inclusions was not necessary. This is also
Fig. 13 Diffractograms of the samples from Haillot ( $y=$ counts square roots). The PDF reference corresponds to the powder diffraction file in the ICDD database

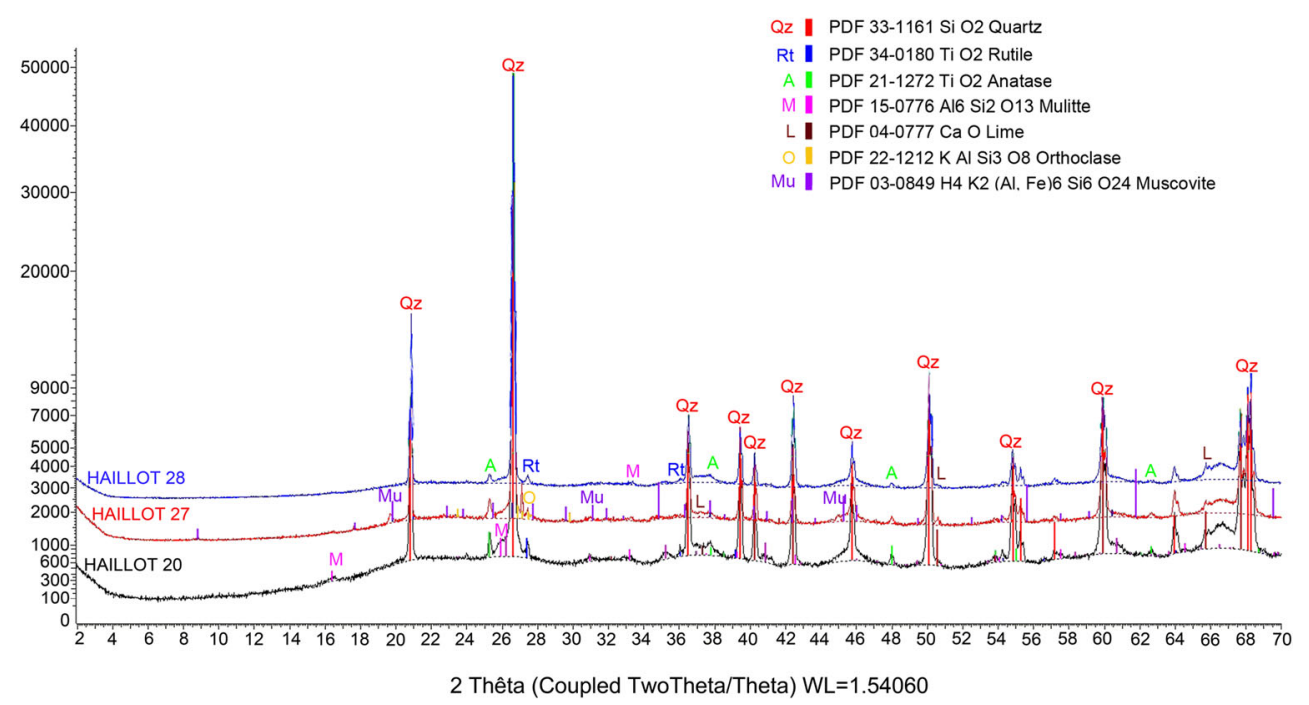


Fig. 14 Diffractograms of the samples from Visé ( $\mathrm{y}=$ counts square roots). The PDF reference corresponds to the powder diffraction file in the ICDD database

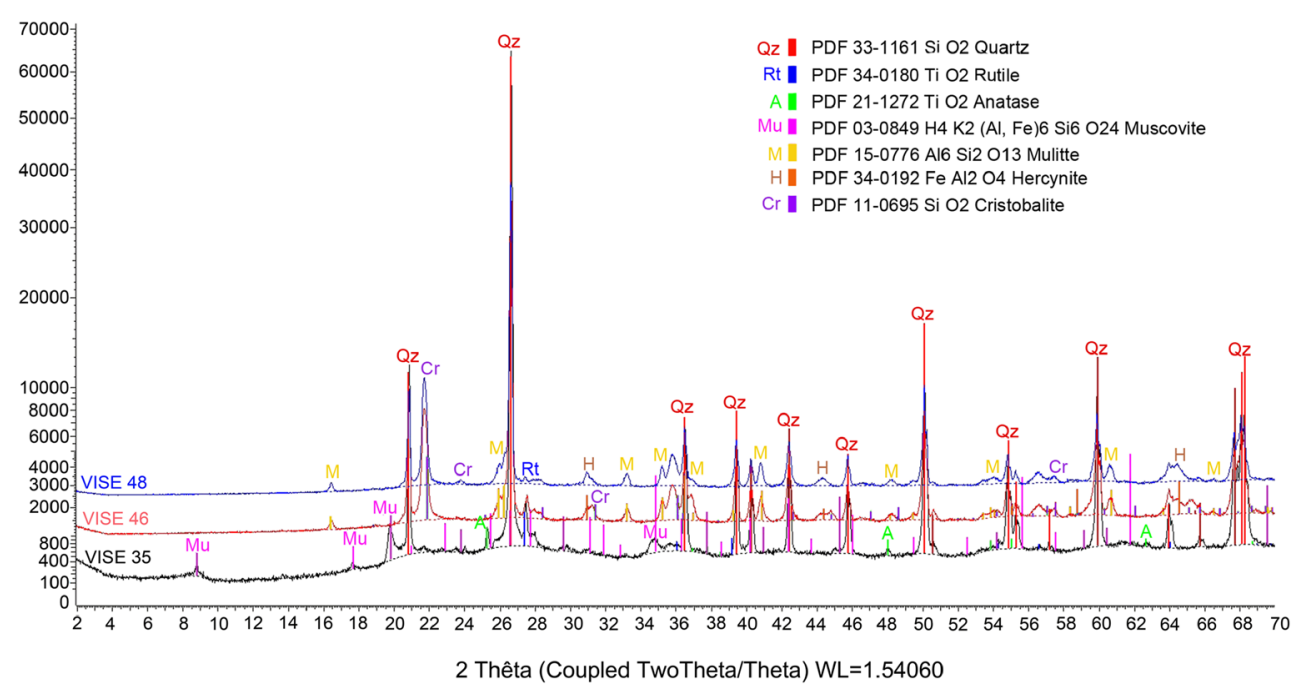

Even if, Ohey 19 that holds muscovite might be fired at a slightly lower temperature, no major changes of temperature seem to happen between the Merovingian and the Carolingian period, the ranges reached were probably quite close. As discussed below, in Gérin, other minerals testify these temperatures. The sherds of Visé show a wider range of firing temperature but this is probably due to the presence of misfired and overfired in the samples.

\section{Characterization of the Carolingian workshops}

Even if the clay material is not chemically identical, the potters were obviously looking for whitish plastic earth. In all the thin sections, non-plastic inclusions are of two different sizes so the potters had to share similar preparation processes or, at least, they had the same idea on the texture and appearance of the paste meant for pottery production. On all the sites, only one type of clay was used.

Next to the typological and decoration differences revealed by the archeological studies (de Longueville 2015; de Longueville and Vanmechelen 2017), the distinctions between the different Carolingian productions are due to the available clay resources around the workshops. The potters of Visé did not use pure kaolinitic clay. On the other hand, the workshop of Haillot used clay material with a high content of alumina and less traces elements than in the one used in Gérin where higher contents of iron, cobalt, nickel, and zinc have been noticed.

In Gérin, gehlenite, that is absent elsewhere (Figs. 11, 12, 13 , and 14), is identified in all the sherds analyzed by XRD. The question of gehlenite's presence has been discussed several times. In illitic calcareous clays, the appearance of gehlenite is usually linked to the temperature of firing $\geq$ $900{ }^{\circ} \mathrm{C}$ (Maggetti 1982; Rasmussen et al. 2012). Still, in fired clays with a narrow and small grain size distribution, gehlenite is not identified, whereas coarser ware with large calcite grains 
has a significant amount of gehlenite. So, the reaction rate of gehlenite formation is a function of grain size that depends on the processing of the clay (Maggetti and Küpfer 1978). In Gérin, the Ca quantity is quite low and no large calcitic inclusion was observed. Still, in Autelbas, a production using kaolinitic clays with low $\mathrm{Ca}$ values, gehlenite was also identified and proved to appear around $800{ }^{\circ} \mathrm{C}$ (Goemaere et al. 2014).

In Visé, despite the higher content in $\mathrm{Ca}$ and the identification of micritic limestone, the absence of gehlenite might be questioned. In Visé 35, a white and friable sherd, its absence is due to the firing temperature below $750^{\circ} \mathrm{C}$. Indeed, this sample has muscovite and no mullite. Moreover, in this sample, few micritic limestones have been seen. On the opposite, the sherds Visé 46 and 48 show a darker color and a hard paste. Their chemical composition is not distinctive in the sample of this site. In the thin sections, the clay contained some dark nodules but these could not be identified. Mullite, rutile, but also spinel, and cristobalite were seen. Quartz is also lower in Visé 46 and V48 and anatase is not detected (Fig. 14). The presence of cristobalite that can appear around $1000{ }^{\circ} \mathrm{C}$ (Goemaere et al. 2014) attests to a higher firing degree of these two samples. The $\mathrm{Ca}$ could have entered an amorphous phase.

The variations among the samples of Haillot that is observed in XRD analyses and in the chemical compositions are due to the nature of the site and to the sampling strategy. The settlement was occupied during quite a long period and the selected sherds come from the different kilns so they illustrate a variety in time and/or the heterogeneity of the clay used by the potters. On the other hand, the workshops of Gérin and Visé might have had a smaller or more sporadic production. Excavation in the vicinity of the first discoveries might also reveal other remains of potters' activities.

About the kilns fragments, the sample Gérin 14 is totally different and might come from another type of structure or maybe from a floor. Gérin 15 and Haillot 5 have identical compositions to the pottery. So, the clay certainly came from the same source. Now, on both sites, distinctions can be made in the distribution of non-plastic inclusions that is much more heterogeneous in the kilns fragments than in the pottery as already noticed above. Still, from only one sample on each site, it will be difficult to deduce a specific clay preparation for kilns and a wider study of these production structures is suitable.

\section{Location of the workshops and the potters' settlements dynamics}

Between the end of the fifth and the end of the seventh century, in the Meuse region, potters seemed to preferably settle in agglomerations. The kilns found in Huy, Maastricht, and Namur (Vanmechelen 2007; Vanmechelen et al. 2007; Vanmechelen and de Longueville 2007b; Vanmechelen 2013; Van Wersch 2016; de Longueville and Vanmechelen
2017; Vanmechelen et al. 2018; Bosquet et al. 2018) proved that pottery production, as many other crafts activities, were concentrated in these places gathering consumers and communication means such as the roads and rivers (Van Wersch et al. to come). In these locations, raw materials were also available (Van Wersch et al. 2015). Next to these "urban" artisans, rural producers existed as the one identified from the sherds of Ohey or the one of Marilles where a kiln was excavated (Mercenier 1962). There, potters also exploited local plastic earth, apparently with non-discriminating strategies.

With the change to white ceramic, the Carolingians craftsmen specifically selected whitish clays, in particular kaolinitic materials, as proved for other regions (Châtelet et al. 2005). The modification in the supply strategy certainly influenced the choice of the place for the settlement of workshops. Indeed, in the Meuse region, kaolinitic clay is located in specific areas (Goemaere 2017). If the supply had to be regular, it would have been more cost-effective for the Carolingian potters to settle close to a source of raw material. However, other socio-economic factors could have influenced their choice as already observed for the roman productions where potters settled near the clay deposits or in the agglomeration (Biegert et al. 2004). In this view, the production of Visé has to be distinguished from those of Haillot and Gérin.

Situated on the Meuse river, Visé is called a "pre-urban" center. Attested in the tenth century by written sources, its trade fair might have attracted people from the hinterland (Zoller 1974). This could explain the need for ceramic supply. The geology in the region of Visé is different. Clay deposits are attested but no tertiary clay deposits such as those of the Condroz occur (Forir 1896). As the less fired sherds appear white, whitish raw material had to exist in the region and potters might have tried to use it. Still, fired on a higher degree, the clay is more orange/pinkish and one can wonder if these wares were diffused and if the production was lasting.

Conversely, the large number of kilns shows that the workshop of Haillot was productive. The potters had access to good quality material and certainly exported a part of their productions (de Longueville and Vanmechelen 2017). Even if no continuity is proven, a community existed before the tenth century as shown by the Merovingian cemetery found at some hundred meters of the Carolingian settlement (Vanmechelen and Vrielynck 2009). On this site, the presence of elite attracting craftsmen is not proved. On the other hand, we cannot ignore the Benedictine Abbey of Andenne, founded in 692 by saint Begge, on the Meuse, $6 \mathrm{~km}$ from Haillot, located on the edge of the abbey's original domain. From the middle of the eleventh century, the abbey of Andenne became important in ceramic production. It could have had a role in the selection of craftsmen and textual evidence reveals the rights that it exercised on the plastic clay of the Condroz (Melin 1928; Rousseau 1956; Borremans and Lassance 1956; 
de Longueville and Vanmechelen 2017). Still, for the period considered, we have no clue and a community of potters could have developed in Haillot independently because of the presence of suitable material that would have allowed their activity to be successful. Then, it would be placed under the authority of the abbey that became stronger in time.

\section{Conclusion and perspectives}

The white clay from the Mosan region was used during the Roman period (Hanut and Vanmechelen 2017; Rekk et al. 2014) and since that time, it remained a sustainable resource. This paper showed that, even if it was not for its color or for its specific technical properties, Merovingian potters used it when it was available close to their workshops. The clay was extracted and prepared in two different ways according to the type of wares and to their functions.

Between the end of the seventh and the tenth centuries, a clear technical change occurred between the Merovingian and the Carolingian productions. The kaolinitic clay was specifically selected for its properties and the potters were looking for a whitish material. The preparation techniques were also different and led to a more homogeneous process with only one type of preparation for all the forms. In the Carolingian times, the firing temperature does not seem to increase in comparison with the Merovingian period. Variations are observed inside the different workshops but these might be due to misfiring.

The missing link between the Carolingian and Merovingian productions is the eight-ninth century (Theuws 2007). Some of the technical changes must have happened in that period (Demolon and Verhaeghe 1993; de Longueville 2006; de Longueville and Vanmechelen 2017). The group of "MOSA 6" identified by de Longueville is mainly produced in that time (de Longueville et al. 2006). These wares made of white clay have smoked and dark surfaces. Still, the material used remains unclear and the production places have to be found.

This paper was a first step in the petrographic, mineralogical, and chemical study of the Carolingian productions that have to be fully studied. As the site of Haillot was widely excavated and as kilns were discovered, it offers the possibility to focus on production structures and their functioning. The number of samples and analyses should be increased to fully understand the firing process. The exact provenance of the clay resources should be researched. Studies on paints and glazes could also be pursued. Nevertheless, thanks to the characterization of the productions and to the consumption sites discovered, it is now possible to follow the dissemination of the products of each workshop.

It is now clear that the Andenne productions rely on a long pottery tradition. It also appears that things happen in a specific region and there should be a link between the potters of Huy, Haillot, and Andenne, located within a 15-km radius. In that regard, the role of the elite may be nuanced in the settlement strategy of the craftsmen, at least for the beginning of the Middle Ages. The presence of natural resources was also a key factor because it may have influenced the location of the potters' workshops and then focalized the attention of "aristocrats."

Acknowledgments The present research has been done in the frame of the Interuniversity Attraction Pole 07/09 project CORES - Comparing regionality and sustainability in Pisidia, Boeotia, Picenum, and NW Gaul between Iron and Middle Ages (1000 BC-AD 1000), granted by Belspo - Belgian Science Policy Office, 2012-2017. The writing was finalized thanks to an ERC advanced grant and the project "Rural Riches". We would like to thank the AWAP (Agence wallonne du patrimoine) that gave us access to the material coming from its excavations as well as the archeologists. Finally, we express our deep gratitude to Dr. E. Goemaere and to Pr. Fr. Theuws who read the paper and advised us on the subject as well as the anonymous reviewers for their constructive remarks.

Funding information The ICP-MS at the Field Museum was funded by a NSF MRI Grant (1531394). This article was finalized as part of the Rural Riches project which is funded by the ERC under the ERC-Advanced Grant (Grant agreement No.741340).

Open Access This article is licensed under a Creative Commons Attribution 4.0 International License, which permits use, sharing, adaptation, distribution and reproduction in any medium or format, as long as you give appropriate credit to the original author(s) and the source, provide a link to the Creative Commons licence, and indicate if changes were made. The images or other third party material in this article are included in the article's Creative Commons licence, unless indicated otherwise in a credit line to the material. If material is not included in the article's Creative Commons licence and your intended use is not permitted by statutory regulation or exceeds the permitted use, you will need to obtain permission directly from the copyright holder. To view a copy of this licence, visit http://creativecommons.org/licenses/by/4.0/.

\section{References}

Arnold DE (1985) Ceramic theory and cultural process. Cambridge University Press, Cambridge

Arnold PJ (2000) Working without a net: recent trends in ceramic ethnoarchaeology. J Archaeol Res 8(2):105-133. https://doi.org/ 10.1023/A:1009452310915

Arnold DE (2006) The threshold model for ceramic resources: a refinement. In: Gheorghiu D (ed) Ceramic studies: papers on the social and cultural significance of ceramics and Europe and Eurasia from prehistoric to historic times, vol 1553. BAR International Series, Oxford, pp 3-9

Arnold DE, Neff H, Bishop R (1991) Compositional analysis and "sources" of pottery: an ethnoarcheological approach. Am Anthropol 93:70-90. https://doi.org/10.1525/aa.1991.93.1. 02a00040

Biegert S, Deru X, Fronteau G, Paicheler JC (2004) Les productions du « groupe de pâtes champenois " : caractérisations archéologiques, 
pétrographiques et chimiques. Revue du Nord 358:135-161. https:// doi.org/10.3917/rdn.358.0135

Bishop L, Rands RL, Holley GR (1982) Ceramic compositional analysis in archaeological perspective. Adv Archaeol Method Theory 5:275330 https://www.jstor.org/stable/281452

Borremans R, Lassance W (1956) Les potiers d'Andenelle au moyen âge : un aspect peu connu de la vie économique mosane. Parcs Nationaux 11:70-75

Borremans R, Warginaire R (1966) La céramique d'Andenne. Recherches de 1956-1965. Stichting het nederlandse gebruiksvoorwerp, Rotterdam

Bosquet D, Vanmechelen R, Bielen A, Delaunois E, Devillers C, Gérard P-B, Hardy C, Incoul I, Lavachery P, Loicq S, Martin F, Pierlot A, Ritzenthaler S, Robert J, Timmermans J, Van Buylaere M, Van Eetvelde C, Venant N (2018) Namur/Namur : premiers résultats de l'opération d'archéologie préventive au Grognon (marsdécembre 2017). Chronique de l'Archéologie Wallonne 26:210 219

Braekmans D, Degryse P (2016) Petrography: optical microscopy. In: Hunt A (ed) The Oxford handbook of archaeological ceramic analysis. Oxford University Press, Oxford, pp 233-265. https://doi.org/ 10.1093/oxfordhb/9780199681532.013.15

Challe S, de Longueville S, Lepot A (2014) De la cuisine à la table dans des pots de terre. Vie Archéologique 72:31-37

Châtelet M (2002) La céramique du haut Moyen Âge du sud de la vallée du Rhin supérieur (Alsace et Pays de Bade), typologie, chronologie, technologie, économie et culture. Editions Monique Mergoil, Montagnac

Châtelet M, Picon M, Thierrin Michael G, Waksman Y (2005) Production et diffusion de la céramique pendant le Haut Moyen Âge dans le sud du Rhin supérieur. Un programme d'analyse sur la production de la céramique en Alsace et en Pays de Bade pendant la période du haut Moyen Âge Archéologie médiévale 35:11-38

Cogswell J, Neff H, Glascock M (1996) The effect of firing temperature on the elemental characterization of pottery. J Archaeol Sci 23:283287. https://doi.org/10.1006/jasc.1996.0026

Costin CL (2000) Thinking about production: phenomenological, classification and lexical Semantics. Archeol Pap Am Anthropol Assoc 17(1):143-162. https://doi.org/10.1525/ap3a.2007.17.1.143

de Longueville $\mathrm{S}$ (2006) La céramique du VIII ${ }^{\mathrm{e}}$ au XI ${ }^{\mathrm{e}}$ siècle dans la vallée de la Meuse moyenne. Productions régionales et importations rhénanes et de l'Eifel. In: Menniken R (ed) Keramik zwischen Rhein und Maas. Keramische Begegnungen mit Belgien und den Niederlanden, Beiträge zum 38. Internationalen HafnereiSymposium des Arbeitskreises für Keramikforschung im Töpfereimuseum Raeren (B), vom 19. bis zum 24. September 2005. Töpfereimuseum, Raeren, pp 55-61

de Longueville S (2008) La diffusion de la céramique andennaise. In: Wallonia Nova. La Meuse médiévale ; redécouverte d'un patrimoine. Les éditions du Confluent, Jambes, pp 46-47

de Longueville S (2009) Visé/Visé. Découverte fortuite d'un four de potier médiéval Chronique de l'Archéologie wallonne 16:125-128

de Longueville $\mathrm{S}$ (2015) Les sites de production de céramiques aux $\mathrm{X}^{\mathrm{e}}$ et $\mathrm{XI}^{\mathrm{e}}$ siècles dans la vallée de la Meuse moyenne (Belgique). In: Thuillier F, Louis E (eds) Tourner autour du pot... Les ateliers de potiers médiévaux du $\mathrm{V}^{\mathrm{e}}$ au XII ${ }^{\mathrm{e}}$ siècle dans l'espace européen, Actes du colloque international de Douai (5-8 octobre 2010). Publications de CRAHM - Centre Michel de Boüard - Centre de recherches archéologiques et historiques médiévales, Caen, pp 351360

de Longueville S, Challe S (2016) De l'argile au pot. Archéologie expérimentale en Condroz. Les dossiers d'Archeolo-J. http://www. archeolo-j.be/sites/default/files/contenu/fichiers/arc0303echoprintemps2017.pdf

de Longueville S, Plumier J (2007) Les fours de potiers de Mozet (Gesves, prov. de Namur/Belgique.). In: Heege A (ed) Töpferöfen-
Pottery kilns-Four de potiers. Die Erforschung frühmittelalterlicher bis neuzeitlicher Töpferöfen (6.-20. Jh.) in Belgien, den Niederlanden, Deutschland, Österreich und der Schweiz, Basler Hefte zur Archäologie, 4, Basel, pp 245-262

de Longueville S, Vanmechelen R (2017) Haillot et les ateliers de potiers ruraux du Premier Moyen Âge: une économie organisée au départ des campagnes. In: Piechowski C (dir) La derle - Li dièle. L'habile argile du Condroz. Vingt siècles de céramiques en terres d'Andenne. Les Dossiers de l'IPW, 22, Namur, pp 113-121

de Longueville S, Verbeek M (2010) Onhaye/Gérin (Nr.) : une nouvelle production de céramique médiévale mosane? Archaeologia Mediaevalis 33:52-55

de Longueville S, Mees N, Robinet C, Vanmechelen R, Collette O (2006) Le Grognon (Namur, Belgique) : un site de consommation au secours de la recherche céramologique du $\mathrm{VIII}^{\mathrm{e}}$ au $\mathrm{XI}^{\mathrm{e}}$ siècle. In: Hincker V, Husi Ph (eds) La céramique du Haut Moyen Âge dans le nord-ouest de l'Europe ( $\mathrm{V}^{\mathrm{e}}-\mathrm{X}^{\mathrm{e}}$ siècles), Actes du colloque de Caen, 18-20 mars 2004 : bilan et perspectives dix ans après le colloque d'Outreau. Publications de CRAHM - Centre Michel de Boüard Centre de recherches archéologiques et historiques médiévales, Caen, pp 107-129

Debast A, Schimtt A (2003) Techniques et méthodes d'études. In: Verhaeghe F, Desbat A, Garcia D, D'Anna A, Schmitt A (eds) La céramique. La poterie du Néolithique aux Temps modernes. Errance, Paris, pp 9-31

Degryse P, Braekmans D (2014) Elemental and Isotopic Analysis of Ancient Ceramics and Glass. In: Cerling $\mathrm{T}$ (ed) Bookseries: Treatise on Geochemistry, vol: 14, Treatise on Geochemistry, Archaeology and Anthropology, Chapt. 14. Elsevier, Oxford, pp 191-207. https://doi.org/10.1016/B978-0-08-095975-7.01215-8

Demolon P, Verhaeghe Fr (1993) La céramique du Ve au Xe siècle dans le nord de la France et la Flandre belge. Etat de la question. In: Piton $\mathrm{P}$ (ed) La céramique du Ve au Xe siècle dans le Nord-Ouest de l'Europe. Actes du colloque d'Outreau, du 10-12 avril 1992, Nord-Ouest archéologie, pp 385-407

Dussubieux L, Golitko M, Williams PR, Speakman J (2007) LA-ICP-MS analysis applied to the characterization of Peruvian Wari ceramics. In: Glascock MD, Speakman RJ, Popelka-Filcoff RS (eds) Archaeological chemistry: analytical methods and archaeological interpretation, ACS publication series 968. American Chemical Society, Washington DC, pp 349-363. https://doi.org/10.1021/bk2007-0968.ch019

Forir H (1896) Carte géologique de la Belgique. 108, Visé - FouronSaint-Martin, Echelle 1/40.000, Institut cartographique militaire, Bruxelles

Fowler K, Middleton E, Fayek M (2019) The human element: discerning the effects of potter's behavior on the chemical composition of ceramics. Archaeol Anthropol Sci 11:171-198. https://doi.org/10. 1007/s12520-017-0535-0

Goemaere E (2017) « Terre à terres » : quelques mots sur la formation de la derle à Andenne et les communes voisines. In: Piechowski C (dir) La derle - Li dièle. L'habile argile du Condroz. Vingt siècles de céramiques en terres d'Andenne. Les Dossiers de l'IPW, 22, Namur, pp 19-33

Goemaere E, Quinif Y (2010) La géologie des terres plastiques d'Andenne. In: Goemaere E (ed) Terres, pierres et feu en vallée mosane. L'exploitation des ressources naturelles minérales de la commune d'Andenne : géologie, industries, cadre historique et patrimoines culturel et biologique, Service Géologique de Belgique, Institut Royal des Sciences naturelles de Belgique, Imprimerie Chauveheid, Stavelot, pp 373-386

Goemaere E, Henrotay D, Collette O, Golitko M, Delbey T, Leduc T (2014) Caractérisation de la céramique médiévale d'Autelbas (Arlon, Belgique) et identification de la source de la matière première. Archeosciences, Revue d'archéométrie 38:31-47. https://doi.org/10.4000/archeosciences.4127 
Golitko M, Dussubieux L (2016) Inductively coupled plasma mass spectrometry (ICP-MS) and laser ablation inductively coupled plasmamass spectrometry (LA-ICP-MS). In: Hunt A (ed) The Oxford handbook of archaeological ceramic analysis. Oxford University Press, Oxford, pp 399-423. https://doi.org/10.1093/oxfordhb/ 9780199681532.013 .23

Gratuze B (1999) Obsidian characterization by laser ablation ICP-MS and its application to prehistoric trade in the Mediterranean and the near east: sources and distribution of obsidian within the Aegean and Anatolia. J Archaeol Sci 26:869-881. https://doi.org/ 10.1006/jasc. 1999.0459

Gross U (1991) Mittelalterliche Keramik zwischen Neckarmündung und schwäbischer Alb, Theiss, Stuttgart

Hanut Fr, Vanmechelen R (2017) L'artisanat de la céramique dans la vallée de la Meuse à la période romaine : origines, chronologie. In: Piechowski C (dir) La derle - Li dièle. L'habile argile du Condroz. Vingt siècles de céramiques en terres d'Andenne. Les Dossiers de l'IPW, Namur, pp 65-96

Harbottle G (1976) Activation analysis in archaeology. In: Newton G (ed) Radiochemistry. The Chemical Society, London, pp 33-72. https:// doi.org/10.1039/9781847556882-00033

Henning J (2007) Early European towns: the way of economy in the Frankish area between dynamism and deceleration 500-1000 AD. In: Henning $\mathrm{J}$ (ed) Post-Roman towns: trade and settlement in Europe and Byzantium, vol 1. W. De Gruyter, Berlin, pp 3-40

Hurst JG (1969) Red-painted and glazed pottery in Western Europe from the eight to the twelfth century. Mediev Archaeol 13:93-147. https:// doi.org/10.1080/00766097.1969.11735317

Lebecq S (2000) The role of monasteries in the systems of production and exchange of the Frankish world between the seventh and ninth centuries. In: Hansen IL, Wickham C (eds) The long eight century, production, distribution and demand. Brill, Leiden, pp 121-148

Legoux R, Perin P, Vallet F (2010) Chronologie normalisée du mobilier funéraire mérovingien entre Manche et Lorraine. Bulletin de liaison de l'Association française d'Archéologie mérovingienne, SaintGermain-en-Laye

Maggetti M (1982) Phase analysis and its significance for technology and origin. In: Olin JS, Franklin AD (eds) Archaeological ceramics. Smithsonian Institution Press, Washington DC, pp 121-133

Maggetti M, Küpfer T (1978) Composition of the terra sigillata from la péniche (vidy/Lausanne, Switzerland). Archaeometry 20:183-188. https://doi.org/10.1111/j.1475-4754.1978.tb00229.x

Maggetti M, Rossmanith M (1981) Archaeothermometry of kaolinitic clays. Revue d'Archéométrie, Supplément 5:185-194

Melin A (1928) Une Cité carolingienne. Histoire de la ville et du Ban d'Andenne. H. Vaillant- Carmanne, Liège

Mercenier L (1962) Marilles : découverte d'un four de potier du Haut Moyen Âge au lieu-dit "Mossembais". Bulletin du cercle archéologique Hesbaye-Condroz 9:60-64

Mommsen H (2007) The importance of the 'best relative fit factor' when evaluating elemental concentration data of pottery demonstrated with Mycenaean sherds from Sinda, Cyprus. Archaeometry 49: 359-371. https://doi.org/10.1111/j.1475-4754.2007.00306.x

Neff H, Bishop L, Sayre EV (1988) Simulation approach to the problem of tempering in compositional studies of archaeological ceramics. J Archaeol Sci 15:159-172. https://doi.org/10.1016/0305-4403(88) 90004-0

Neff H, Bishop L, Sayre EV (1989) More observations on the problem of tempering in compositional studies of archaeological ceramics. J Archaeol Sci 16:57-69. https://doi.org/10.1016/0305-4403(89) 90056-3

Pearce NJG, Perkins WT, Westgate JA, Gorton MT, Jackson SE, Neal CR, Chenery SP (1997) A compilation of new and published major and trace element data for NIST SRM610 and SRM612 glass reference materials. Geostand Newslett 21:114-115. https://doi.org/10. 1111/j.1751-908X.1997.tb00538.x
Quinn P (2013) Ceramic petrography: the interpretation of archaeological pottery and related artefacts in thin section. Archeopress, Oxford

Rasmussen K, De la Fuente G, Bond A, Matheisen K, Vera D (2012) Pottery firing temperatures: a new method for determining the firing temperature of ceramics and burnt clay. J Archaeol Sci 39:17051716. https://doi.org/10.1016/j.jas.2012.01.008

Rekk S, Laduron D, Yans J (2014) Méthodologie et essai de détermination de constitution de terroirs géochimiques : application aux céramiques communes d'ateliers du Nord de la Gaule. Signa 3: $157-166$

Rousseau F (1956) Andenne. Aperçu de son histoire et de son folklore. Parcs Nationaux 11:65-70

Rye O (1976) Keeping your temper under control: materials and manufacture of a Papuan potter. Archaeology and physical anthropology in. Oceania 11:106-107. https://doi.org/10.1002/j.1834-4453.1976. tb00245.x

Siegmund Fr (1998) Merowingerzeit am Niederrhein : Die fruhmittelalter Funden aus dem Regierungsbezirk Dusseldorf und Kreis Heinsberg (Rheinischen Ausgrabungen), Bonn

Stoltman JBJ, Marcus JJ, Flannery KVK, Burton JHJ, Moyle RGR (2005) Petrographic evidence shows that pottery exchange between the Olmec and their neighbors was two-way. Proc Natl Acad Sci 102:11213-11218. https://doi.org/10.1073/pnas.0505117102

Theuws F (2007) Where is the eight century in the towns of the Meuse valley? In: Henning J (ed) Post-Roman towns, trade and settlement in Europe and Byzantium, vol. 1. The heirs of romans west. W. De Gruyter, Berlin, pp 153-164

Tite MS (1999) Pottery production, distribution, and consumption - the contribution of the physical sciences. J Archaeol Method Theory 6: 181-233. https://doi.org/10.1023/A:1021947302609

Tite MS (2008) Ceramic production, provenance and use e a review. Archaeometry 50(2):216-231. https://doi.org/10.1111/j.14754754.2008.00391.x

Tys D, Loveluck C (2006) Coastal societies, exchange and identity along the channel and southern North Sea shores of Europe, AD 600 1000. J Marit Archaeol 1:140-169. https://doi.org/10.1007/ s11457-006-9007-x

Van Wersch L (2011) Céramique et verres mérovingiens dans la vallée mosane. Apports de l'archéologie et de l'archéométrie à l'histoire économique, sociale et culturelle, Doctoral dissertation, Liège University

Van Wersch L (2016) Merovingian ceramic and glass in the early towns of the Middle Meuse valley, early towns and artisan production in the Low Countries (500-1200). Mediev Mod Matters 4:133-154. https://doi.org/10.1484/J.MMM.5.109448

Van Wersch L, Vrielynck O (2008) Étude du matériel céramique d'un dépotoir mérovingien en province de Namur (Belgique). In: Guillaume J, Peytremann E (eds) L'Austrasie, société, économies, territoires, christianisation. Actes des XXVIe Journées internationales d'archéologie mérovingienne. Presses universitaires de Nancy, Nancy, pp 163-170

Van Wersch L, Mathis F, Coquinot Y, Bouquillon A (2015) Les ateliers de potiers mérovingiens dans la vallée mosane : Étude des productions, In: Thuiler F, Louis E (eds) Tourner autour du pot... Les ateliers de potiers médiévaux du Ve au XIIe siècle dans l'espace européen. Actes du colloque international de Douai (5-8 octobre 2010), Publications de CRAHM - Centre Michel de Boüard Centre de recherches archéologiques et historiques médiévales, Caen, pp 487-49

Vanmechelen R (2007) Haillot et les potiers mosans. Recherches récentes sur les ateliers de production céramique en Meuse moyenne. In: Van Den Bossche B (dir), L'Art mosan. Liège et son pays à l'époque romane du XI ${ }^{\mathrm{e}}$ au XIII ${ }^{\mathrm{e}}$ siècles. Editions du Perron, Liège, pp 222 229 
Vanmechelen R (2013) Namur, In: Vrielynck O (dir), L'archéologie en Wallonie. L'époque mérovingienne. Carnets du Patrimoine, Vottem, pp 20-22

Vanmechelen R, de Longueville S (2007a) Habitat rural et production céramique : l'atelier de potier de Haillot (Belgique) $\left(\mathrm{X}-\mathrm{XI}^{\mathrm{e}}\right.$ siècles). In: Klapste J, Sommer P (eds) Arts and Crafts in Medieval Rural Environment, Ruralia VI (22nd - 29th September 2005, Dobogoko, Hungary), Brepols, Turnhout, pp 245-262. https://doi.org/10.1484/ M.RURALIA-EB.3.1151

Vanmechelen R, de Longueville S (2007b) Un atelier de potiers du début du Moyen-Age à Haillot (Namur, Belgique). In: Actes du colloque "Medieval Europe 2007 - The Fourth International Conference of Medieval and Modern Archaeology", Université de Paris ISorbonne, 3-8 septembre 2007, Paris. http://medieval-europeparis-2007.univ-paris1.fr/R./Vanmechelen/et/al.pdf

Vanmechelen R, Vrielynck O (2009) Bossut-Gottechain et Haillot (Belgique) : deux cimetières mérovingiens, deux expressions de la sépulture privilégiée. In: Alduc-Le Bagousse A (dir) Inhumations de prestige ou prestige de l'inhumation? Expressions du pouvoir dans l'au-delà ( IV e - XV e siècle) Publications de CRAHM - Centre Michel de Boüard - Centre de recherches archéologiques et historiques médiévales, Caen, pp 23-67

Vanmechelen R, Defgnée A, de Longueville S, Houbrechts D, Mees N, Pigière F, Robinet $C$ (2007) Structures portuaires mérovingiennes sur le confluent Sambre-et-Meuse, à Namur (Grognon, fin VIe-VIIe siècle). In: Verslype L (dir), Villes et campagnes en Neustrie. Sociétés - Economies - Territoires - Christianisation. Actes des XXVe Journées internationales d'archéologie mérovingienne de l'AFAM. Mémoires publiés par l'Association française d'archéologie mérovingienne, T. XVI, Editions Monique Mergoil, Montagnac, pp. 231-248
Vanmechelen R, Bosquet D, Bielen A, Delaunois E, Devillers C, Gérard PB, Hardy C, Incoul I, Lavachery P, Loicq S, Martin F, Pierlot A, Ritzenthaler S, Robert J, Timmermans J, Van Buylaere M, Van Eetvelde C, Venant N (2018) Nouvelle opération d'archéologie préventive au Grognon, à Namur : premiers résultats $(\mathrm{Nr})$. Archaeologia Medievalis 41:211-222

Verhaeghe F (1968) La céramique médiévale : problèmes concernant la glaçure. Berichten van de Rijksdienst voor het Oudheidkundig Bodemonderzoek 18:193-208

Verhaeghe F (1969) III. Belgium. In: Hurst JG (ed) Red-painted and glazed pottery in Western Europe from the eight to the twelfth century, Medieval archaeology 13, pp 106-112

Verhaeghe F (2003) La poterie médiévale et moderne en Europe de l'Ouest. In: Verhaeghe F, Desbat A, Garcia D, D'Anna A, Schmitt A (eds) La céramique. La poterie du Néolithique aux Temps modernes. Errance, Paris, pp 19-113

Verhulst A (2002) The Carolingian economy. Cambridge University Press, Cambridge 2002

Vrielynck O, Dosogne M (2001) Ohey/Goesnes. Un dépotoir mérovingien au château-ferme de Baya Chronique de l'archéologie wallonne 9:212-213

Weaver CE (1976) Clays and clay minerals, vol 24. Pergamon Press, New York, pp 215-218

Weil R, Brady N (2016) The nature and properties of soils, 15th edn. Pearson, Colombus

Zoller C (1974) Le tonlieu de Visé du Xe au XIVe siècle. Acta Historica Bruxellensia 3:7-29 http://carto1.wallonie.be/geologie/viewer.htm

Publisher's note Springer Nature remains neutral with regard to jurisdictional claims in published maps and institutional affiliations. 